Article

\title{
Like Melville on the Leaf of Shakespeare? Olson's Annotations to Ace of Pentacles, by John Wieners
}

\author{
Luke Franklin \\ University of King's College, Halifax, NS B3H 2A1, Canada; Luke.Franklin@ukings.ca
}

Received: 15 February 2019; Accepted: 28 May 2019; Published: 19 June 2019

\begin{abstract}
This article is on the textuality of handwritten marginal inscriptions, and the often acute difficulty of interpreting them. No poet was more profoundly influenced by the agonistics of this interpretative work than Charles Olson (1910-1970). One way to tell the story of his authorship would be to draw a categorical distinction between his life as a scholar of Herman Melville, and his life as a poet associated with the legacy of modernism and with Black Mountain College. However, the marginalia that Olson wrote in his copy of Ace of Pentacles (one of two he owned), by his former student and protégé, John Wieners, tell another story. At one point Olson seems to compare his marginalia in "John's book" (as he calls it) to those Melville wrote "on the leaf of Shakespeare". The annotated "leaf" he has in mind figures in Call Me Ishmael as decisively formative in the making of Moby-Dick. Evidence indicates that Olson used his copy of Ace of Pentacles to devise strategies of writing his way through a major tragedy-the loss of his wife in a car accident in March, 1964. It is amid his annotations that we find the probable starting place of several poems that he wrote to her memory, all controversially excluded from the posthumously published third volume of The Maximus Poems. Yet the marginalia are every bit as resistant to interpretation as those he had himself confronted in the marked pages of Melville's books, and we will need to think carefully about this analogy and its implications. I argue that his marked-up copy of Ace of Pentacles is part of a textual continuum of uncertain extent, raising questions about how we should read the last volume of The Maximus Poems.
\end{abstract}

Keywords: Olson; Wieners; marginalia; annotations; The Maximus Poems; Ace of Pentacles

\section{Introduction}

Charles Olson died in the winter of 1969-1970. Once apprised of his terminal illness, he put his friend Charles Boer in charge of finding a purchaser for his papers, and informed him that there was to be a third book of The Maximus Poems. On the evening of December 19, he asked George Butterick, over the phone, to partner with Boer to assemble the third volume. There could be no detailed itemization of which poems to include and which to omit. He had too little time to draw up any elaborate plans or instructions; and besides, there was nothing he could have done about the state of confusion and disorder in which he had left his manuscripts back in Gloucester (Butterick 1978, pp. xliv-xlv). "Throughout his life, Olson saved much, possibly nearly everything". He wrote prolifically, and he "never threw anything away". ${ }^{1}$ A visitor who came to his household in 1969 thought "the livingroom [sic] looked like a bookshop after an anarchist's bomb!" (Miles 1997, p. 2). It was into this disaster area that Boer ventured in 1970, boxing up his papers for transport to the University of Connecticut, where he and Butterick began their editorial work. ${ }^{2}$

Butterick 1981, p. 82. But see Rumaker 2012, p. 212.

Butterick 1981, pp. 82-83. For more on the condition of his living- and workspace toward the end of his life, see Charters and Olson 2015, pp. 18-19; Corbett 1998, pp. 10-14. 
There were, despite all the obstacles, reliable signposts for them to follow. When The Maximus Poems Volume Three came out in 1975, a full half-decade after Olson's death, Butterick and Boer had every reason to feel they had honored his wishes and faithfully put his intentions, however inchoate, into practice. All they had to say on their own account was contained on one page at the front of the book, in a modest "Editors' Note". "These poems were edited at Charles Olson's request from among his papers"; "Some were published in periodicals before his death" and others, read aloud and recorded on tape. "The arrangement is chronological (spring of 1963 through November of 1969)", on the same principle as volumes one and two, in which the poems also come in chronological order (Olson 1975a, p. 5). It was left implicit that strenuous measures were taken to ensure a continuity of format and appearance with the first two volumes-an editorial principle that, in time, was to come under severe criticism from other quarters. ${ }^{3}$

The modesty of the "Editor's Note" was belied by the long blurb on the back cover, encomiastic and celebratory even by the standards of blurbs:

This volume is the conclusion of twenty years of work and it is a triumph: the Republic is successfully constructed, the Golden Flower attained, and Gloucester stands revealed, a perfect "monstrance forever". It is the conclusion of an epic that stands as a spiritual autobiography as well as an act of history.

Don Byrd, long immersed in the study of Olson's poetry and one of the first to review the new volume, could not agree. "I cannot think it is a triumph", he wrote; "It is a book that I read and re-read, that I wonder about, and at" (Byrd 1976, p. 102). Especially ominous and puzzling to Byrd was the very last poem in the whole book, which had been designated as such by Olson on his hospital bed. This poem is a terse, one-line epigraph, only eight words long. In its entirety, standing alone on the page, it looks roughly like this:

$$
\text { my wife my car my color and myself (Olson 1975a, p. 229) }
$$

Byrd wisely judged the presence of the "car", understood as a personal automobile, an ominous sign. Olson hated cars. He believed "the internal combustion engine" to be the defining "product of a civilization that also turned people into machines". ${ }^{4}$ However, there was something even more ominous about this one-line snippet of poetry that Byrd only noted, at first, in passing, and that forms my point of departure in this article. Boer's memoir of his deceased friend, Charles Olson in Connecticut, is written in the form of a letter to him, and in one passage, we read the following:

It was in a Volkswagen that your wife, Betty, had been killed only five years before [in 1964] in a tragic accident in Buffalo. She had gone out one wintry afternoon to buy groceries. Her car was hit by a drunken driver in a head-on collision. When the State Police appeared at the door to tell you of the accident, you collapsed. Your life was suddenly, incredibly, broken apart. You would never be able to put it back together again. (Boer 1975, p. 19)

In 1963 he had uprooted himself and his family from Gloucester and taken work at the State University of New York, Buffalo. He and his wife, Elizabeth Kaiser-usually called Betty or Bet-and their young son, Charles Peter, found housing about an hour outside the city, in the village of Wyoming. The details are murky, but Olson's biographer, Tom Clark, reports escalating marital tensions that left Betty Kaiser isolated and in despair (pp. 304-8). It was on one of the rural corridors between Wyoming and the nearest large town, Batavia, that she lost her life in an automobile collision on the night before Easter, March 28, 1964. Benjamin Friedlander describes the situation as follows:

3 Maud 1976, pp. 32-33; 1980, pp. 29-30. See Maud 2009, pp. 38-39, for a look back at this quarrel.

4 Byrd 1976, p. 101. But see Boer 1975, p. 91: "all my poems end with an image of the vehicular". 
That death undid Olson, setting him adrift, unable to care for his son, Charles Peter, who was sent to live with Betty's sister. Olson himself settled into a motel, exacerbating already dissolute behavior, and his lack of self-care began to alarm friends. (Clarke 2016, p. 54)

This tragedy, then, not a mood of a "triumph", determines the very last of all The Maximus Poems. When he wrote it his "wife Betty, was already dead, in a car wreck", Byrd tells us; and this needs to be known in all its specificity, otherwise the last poem sounds like some sort of all-too-general "capitulation" (p. 101). The problem was the way this snippet of writing seems bathed in "metaphysical" significance, as though these were the most important eight words in the whole book. But suppose, Byrd asks, other editorial decisions had been made:

There is, for example, a moving sequence of short poems about Betty's death, and, despite Olson's death-bed disavowal of "'weak' affective poetry", the line which he marked for the conclusion of his masterpiece would have gained specific content from these poems. The sadness, loneliness, and resignation would appear less metaphysical. (pp. 111-12)

Byrd had no doubt that Olson's editors had, in the end, made all the right decisions. He could not have left "his manuscript in more capable hands" than those of Boer and Butterick, who had carefully "followed Olson's precedent in the first two volumes" (p. 110). Still, Byrd thought their nondescript "Editors' Note" could have been a bit more detailed. "I do wish the editors had given us, somewhere, a full account of the condition of the manuscript and of the editorial procedure" (p. 109).

A very "full account" indeed was just then already on its way. Byrd had only two short years to wait before Butterick, in A Guide to the Maximus Poems of Charles Olson, gave a full report of all he and Boer had done to assemble volume three. Future users of the Guide, and its supplement, Editing the Maximus Poems, found themselves unexpectedly thrilled by the high drama of the editorial process. Witness an enthusiastic Charles Bernstein, writing in 1985: "Butterick's two books not only elucidate thousands of otherwise inscrutable passages but also chronicle the drama of bringing a textual order out of a manuscript chaos" (C. Bernstein 2001, pp. 335-36). A reader is on their own, however, when it comes to the compositional history of volume three, which can only be gleaned from the individual annotations. An overview or synopsis of Olson's first year-and-a-half of work might look roughly as follows. The new book began its life with the writing of several short poems in the spring of 1963 . His time away at the Vancouver Poetry Conference and then the subsequent move to Buffalo interrupted his work until late December. Olson then wrote expansively and steadily until the time of the car accident, when everything came to a screeching halt. This was where, according to Ralph Maud, Butterick should have said much more than he did:

The momentousness of the sudden death of the poet's wife, killed in an automobile accident on 28 March 1964, which the format of The Maximus Poems Volume Three totally obfuscated, is not much better met by the Guide, whose format seems to allow the death to be mentioned only in passing. (Maud 1981, p. 38)

After the accident, Maud tells us, Olson wrote no more of the sequence for two months, then began anew with an elegiac poem called "Maximus to himself June | 1964". That the "poet's silence from that day in March to 4 June 1964 is not commented on" in the Guide is inexcusable to Maud because, in his opinion, the pathos of this poem depends on our consciousness of it (Maud 1981, p. 38):

Maximus to himself June 1964

no more,

where the tidal river rushes

no more

the golden cloak (beloved 


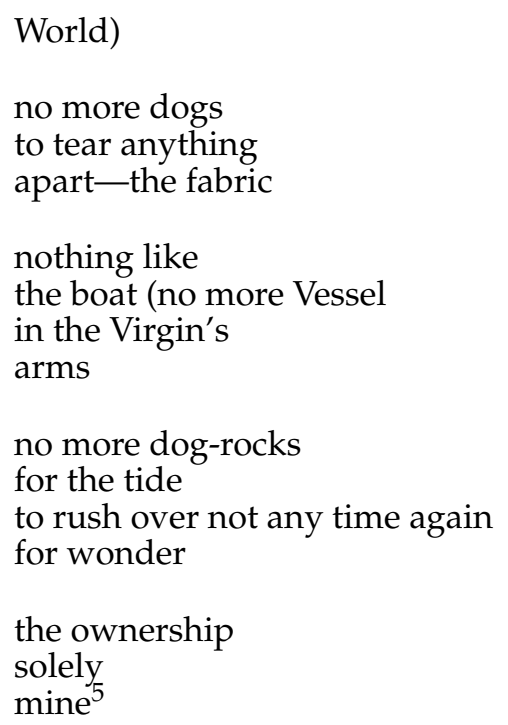

It could be argued that Butterick's eschewing a general compositional history of volume three kept him from detailing instances when Olson's work on it slowed down or ceased altogether. Observing gaps or caesurae in the writing of volume three would have raised questions about its posthumous construction. Did he, for instance, really write nothing worth adding to The Maximus Poems between September 9 of 1964 and January of the next year (Butterick 1978, pp. 574, 613)? That October, Byrd knew, Olson had written his set of poems about Betty Kaiser. Her absence from his life, the "momentousness" of her sudden death does, then, get into the Guide, albeit sometimes only in the negative form of unremarked gaps in the composition of the sequence.

Butterick did, however, mention the poems about Betty Kaiser. He and Boer had no end of hard decisions to make about what to include in volume three and what to keep out of it. Especially "troublesome", he writes, were the following:

Some typed poems written in the period following his wife's death which do include the figure of Maximus but which seemed so private, the way many of the autobiographical poems or passages are not, that to include them would have in fact introduced a new theme, that of personal human love-not Maximus's love-into the poems. It was not ours to do. (Butterick 1978, p. xlix)

Byrd had, in the meantime, come to the opposite conclusion. Charles Olson's Maximus argues that volume three is not necessarily just a continuation or prolongation of the first two. Instead, "The tone has changed". The voice of Maximus falls silent, and that of Olson fills its place (Byrd 1980, p. 170). This judgment was seconded by Michael André Bernstein that same year: evidently, he suggests, Olson "felt the need to speak in his own voice at length and almost with confessional intimacy" (M. A. Bernstein 1980, p. 268). The reader needs to know, Byrd insisted, that "Betty's death left both he and Maximus disoriented. In October, 1964, he wrote a sequence of poems addressed to her, and they would have added resonance to the poems which followed". This "sequence", he maintains, is the key to the difference between the first two volumes and the last one, as "the death of Betty-an event which nowhere appears but which continually haunts all of these poems-occasions a sadness, a sense of Maximus as vulnerable, that is new to the poem" (Byrd 1980, pp. 188, 170-71).

It is, then, in Byrd's opinion, very unfortunate indeed "that the editors chose not to include some of the poems concerning the death of his wife". He reproduces one of the suppressed poems as follows:

5 Olson 1983, p. 420. Besides "Maximus to himself June | 1964" the next most overt reference to Betty Kaiser and her death can be found in "O Quadriga" (Olson 1983, p. 451). In June of 1964 he also wrote about the accident in "barley or rye ... " and "Grinning monster out side the system ... " (Olson 1987, pp. 611-13). 
I went full tilt

and then she was killed

in her automobile

I need every bleeding minute now

I don't have any more time for any new life. (Byrd 1980, p. 188)

No more was heard of this poem, to my knowledge, for over a decade, not until the publication of Tom Clark's biography in 1991. Clark paraphrases as follows: "In one verse fragment he attempted to articulate his feeling that the loss of his wife had somehow derailed him from his own forward track in life, increasing the pressure on him to drive ahead harder than ever" (p. 316).

My purpose in this article is not to adjudicate between different biographical accounts, much less to tell the true story of what happened in the leadup to the accident. ${ }^{6}$ Nor am I arguing, on the side of Byrd, that Boer and Butterick were remiss in their editing of The Maximus Poems Volume Three, or that the poems about Betty Kaiser, the so-called "sequence of poems addressed to her", should have been included in it. Instead, I want to go back to the untitled poem, "I went full tilt", which Byrd has not cited in its entirety. The full version was not published until the spring of 2000, when, in the final issue of Sulfur, and under the editorial curatorship of Ralph Maud, there appeared a five page sequence by Olson entitled simply "Poems for Bet". 7 This sequence includes both "Maximus to himself June | 1964" and also other poems, written both before and after the car accident- "three short poems earlier", in Maud's words, "and six short poems thereafter which we can have no hesitation in adding as poems of love and honor". 8 Olson's melancholy look back at the car wreck of March 28 now appears as follows:

I went full tilt

And then she was killed

in her automobile

I need every bleeding minute now

I don't have any time for any new life

reading John Wieners'

Ace of Pentacles, Friday

October 9th 1964 (Olson 2000a, p. 199)

This follows the original typescript, which is reproduced as Figure 1 . What, then, to make of the three line subtext? John Wieners was a former student of Olson's at Black Mountain College in the 1950s. The two had what Basil King memorialized as an "enviable" relationship of equals that was, in its evenness and reciprocity of mutual respect, exceptional amid Black Mountain's notoriously competitive milieu (King 2010). Their correspondence, however, often suggests something much more one-sided. Keston

6 Boer, we have seen, remembers hearing that Betty Kaiser died on an afternoon drive to get groceries, presumably a lapse of memory or a misunderstanding on his part. Clark 1991 gives the details of the accident and chronicles her fraying relationship with Olson in Wyoming (pp. 304-8). Maud 2008 casts the reliability of Clark's biography in doubt, but does not dispute its account of how he overruled his wife's wishes by relocating them to Buffalo and then, once they were there, often acted oblivious or indifferent to her well-being. See Clarke 2019, p. 16. Research is ongoing on Betty Kaiser and her work see, e.g., Witthus 1998, pp. 9-10.

7 Olson 2000a, pp. 195-200. This was a title of Maud's choosing, and the numbered sequence, a thing of his own making. It is very likely that his selection of "Poems for Bet" includes all of those Byrd had called a "sequence of poems addressed to her" (Byrd 1980, p. 188). But this grouping of "Poems for Bet" does not encompass everything Butterick had in mind when he spoke of "typescripts written in the period following his wife's death" (Butterick 1978, p. xlix). Maud excludes, for example, "A Maximus" ("Annex II: Rejected Poems", Butterick 1983, p. 10).

8 Olson 2000a, p. 195. Maud's opting to publish pre- and post-accident poems together affects the way we read the latter, which may not be "poems of love and honor" at all, but of irreparable loss and despair. Eshleman (who edited Sulfur) was soon to suggest that, in his opinion, Olson "never really recover[ed] from the death of Betty Kaiser" (Eshleman 2004). 
Sutherland is not exaggerating when he says that Olson was "the poet whom Wieners long worshipfully regarded as his infallible mentor and guide" (Sutherland 2012, p. 9). But this idolatry of Olson was over by the time he published his second book of poetry, Ace of Pentacles, under the collaborative imprint of two New York booksellers, James F. Carr and Robert A. Wilson, in September of $1964 .^{9}$

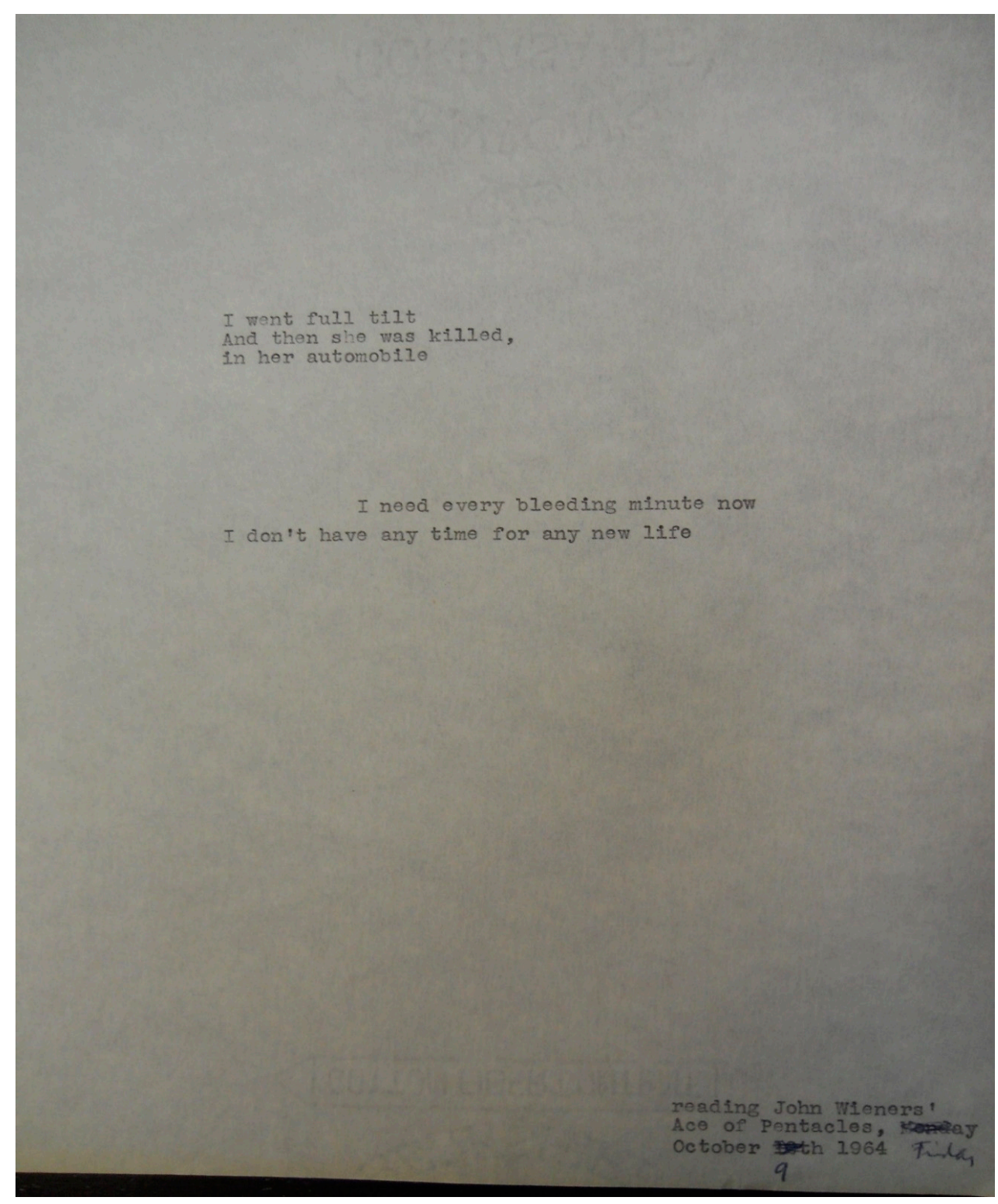

Figure 1. "I went full tilt ... ", box 24, folder 1149, Charles Olson Research Collection. Archives and Special Collections at the Thomas J. Dodd Research Center, University of Connecticut (hereafter CORC).

There are two copies of Ace of Pentacles in Olson's archive. The first of the two is in pristine condition, seemingly unread, preserved with the rest of the books he owned at the time of his death. ${ }^{10}$ There is an inscription on the title page that memorializes the night he and Wieners met in Boston, ten years before:

9 On the making of this book and the circumstances of its publication, see Dewhurst 2014, pp. 107-9; and Stewart 2014, pp. 287-98, 311-12, 314-15, 316-17, 320-47, 354-58 for relevant correspondence.

10 The book is class marked Olson 1154 by CORC. 
To Charles

in hopes that he'1l

smile at me, 10 years from now

as he did, 10 years ago

tonight

on hurricane Hazel, Sept 11, 1954-64

John Wieners ${ }^{11}$

The other copy has been dramatically torn apart, the front and back covers both ripped away, and the front flyleaf remade as a substitute title page, on which Olson has also inscribed something like an alternative table of contents-a list of notes among which his annotations to Ace of Pentacles should be included (see Figure 2):

A

Personal

Book,

owned by me [given to me by Johnny Wieners

Night Sept 11

1964

— \& written in, \& read by me Friday night October 9th 1964

[exactly by the Lord one month

ago

[to be considered to follow

notes Thursday night

[add Saturday day left hospital May

-Themselves to follow Wednesday,

18th (? 1964

October 7th-day [pocket notes still in pocket written at Town \& Country restaurant

Wednesday night-after dining out old [illegible] $\sqrt{ }$

"house" [illegible]

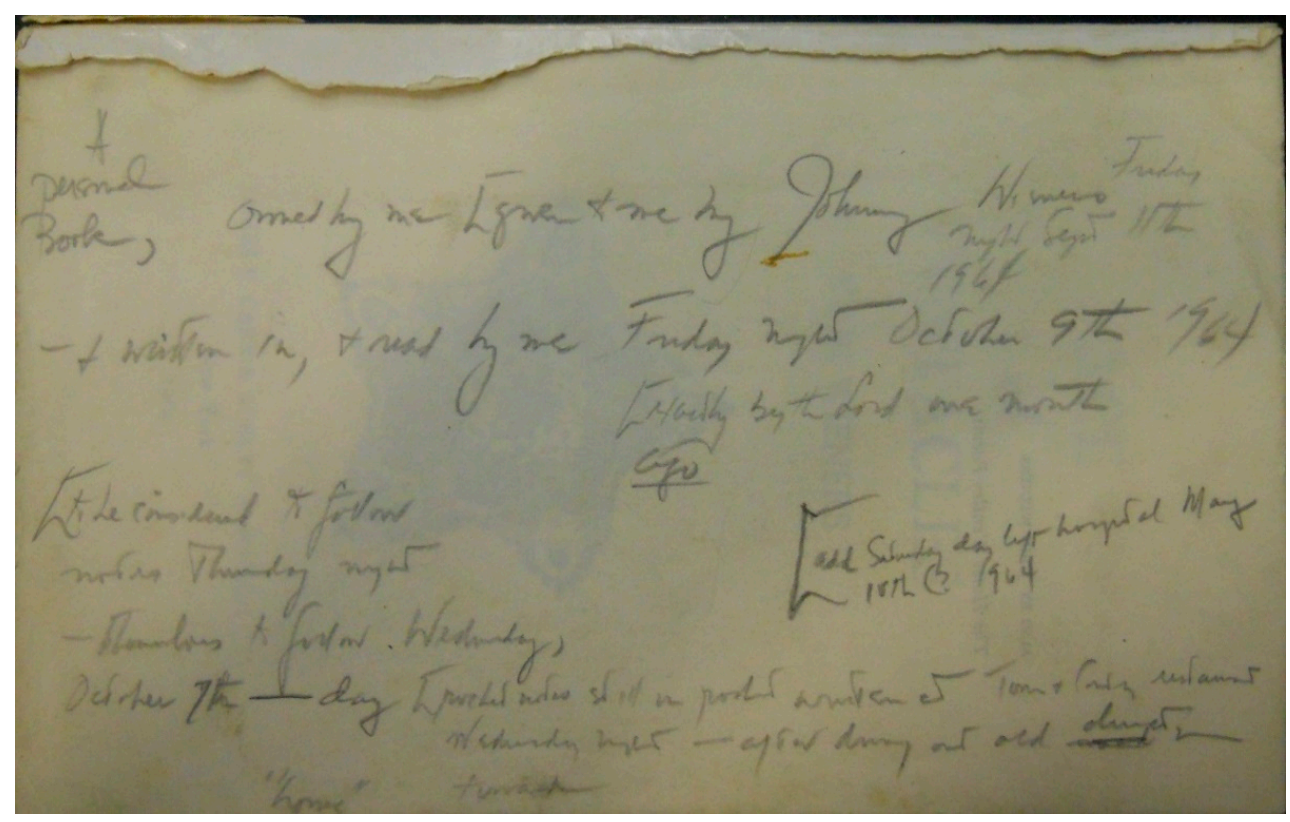

Figure 2. Front flyleaf of "Manuscript. Written on 'Ace of Pentacles' by John Wieners", box 24, folder 1147, CORC.

11 On the circumstances of their meeting, see Dewhurst 2014, pp. 22-23. 
In one of the journals he was using at the time, we find another version of this schema, except with no allusion to May 18th. Ahead of all the other items on what looks like a long to-do list, Olson has written the following:

poems on Bet in notes on John's book

—\& poems night (Thursday notes out?

\& Wednesday-in my jacket pocket ${ }^{12}$

If we turn over the book and look at the heavily annotated rear flyleaf (Figure 3), we find more than mere "notes". At the bottom right corner, continuing up under the centrally-placed author's biography, we see what looks very much like an original draft version of the poem Olson wrote about the car wreck, the one that begins "I went full tilt". Both stanzas of the poem are there, the first linked to the second by a line, which passes through some detached notes on a dream (or a nightmare) he had recently had about his wife.

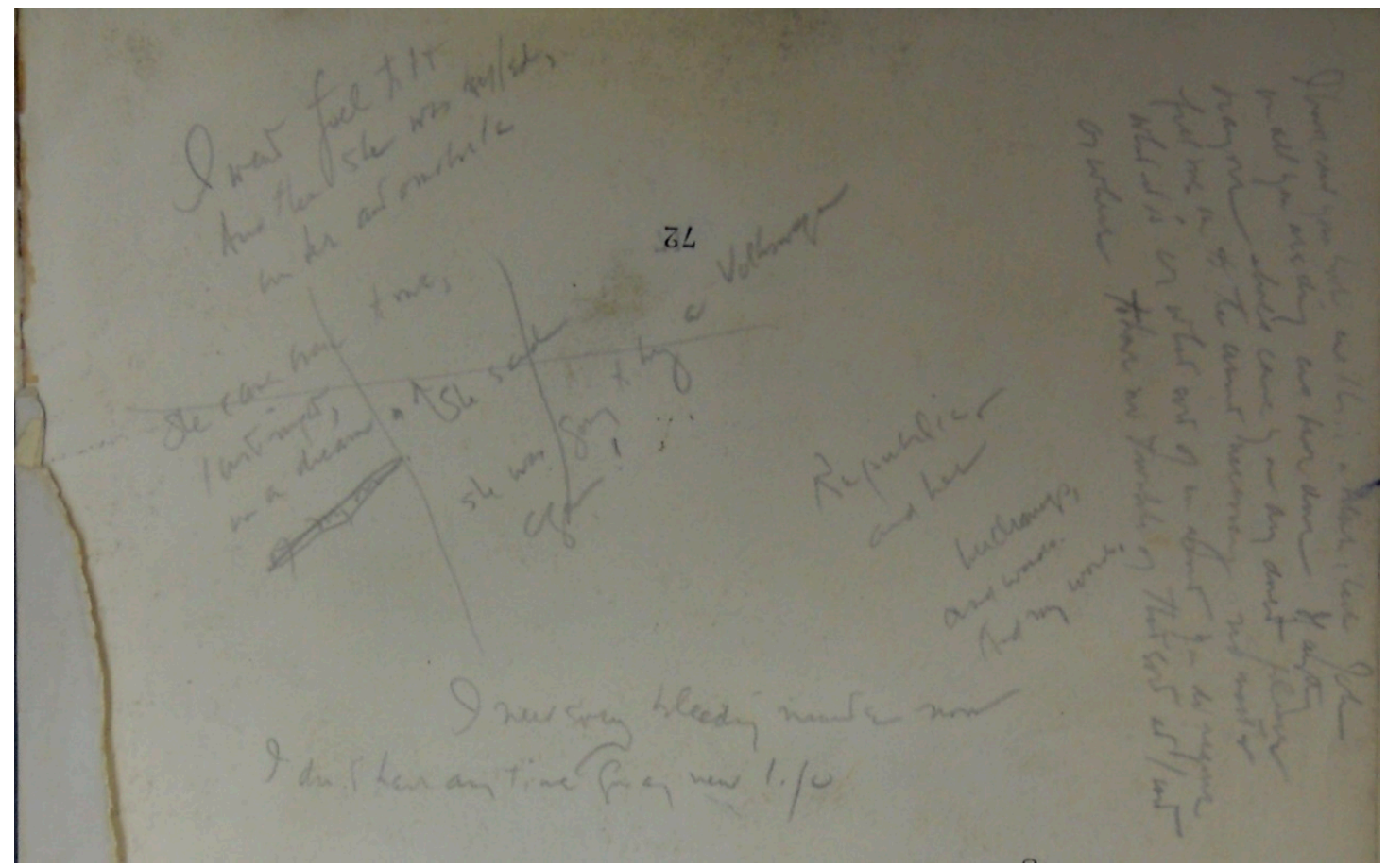

Figure 3. Page 72 of "Manuscript. Written on 'Ace of Pentacles' by John Wieners", box 24, folder 1147, CORC.

On p. 30 we find another of his "poems on Bet", written and transferred to typescript on that same night, October 9th. ${ }^{13}$ A third can be found in the margins of page 34, from whence it, too, has been typed up with few changes of wording and assigned the same date as the others, "Fri Oct 9th".14 This was also the night he composed the poem called "Bet 2", 15 which does not appear inside of Ace of Pentacles. However, this poem opens with the lines, "Her skin | covered me", and on the back of the book Olson has written: "she does cover | your soul". Of the "typed poems written in the period following his wife's death", then, three in total appear to have been written inside of Ace of

\footnotetext{
Notebook. No. 150. October 1964-December 1964, box 65, CORC.

See "Annex II: Rejected Poems", Butterick 1983, p. 8; Olson 2000a, p. 199.

"Going to Bed at Night ..." ", box 24, folder 1168, CORC; Olson 2000a, pp. 198-99. I do not discuss this poem in what follows.

"Her skin covered me ..." ", box 24, folder 1170, CORC. While the finding aid says that this is a titleless poem, the subtext in the bottom right corner suggests otherwise: "Bet 2 (Friday night | October 9". See Byrd 1980, p. 188, for an except of the poem, and Olson 2000a, pp. 199-200, for the full version.
} 
Pentacles, as well as slight traces of a fourth. The inescapable implication is that John Wieners played an important role in their making.

Anyone at work on Olson's book annotations is sure to remember that he, too, had spent countless hours transcribing and analyzing hard-to-read marginal markings. As we will see, his heavily-inscribed copy of Ace of Pentacles at one point directly references the work he had done on Herman Melville's marginalia. It is to this part of his life that we now need to turn.

The young Olson's accomplishments in what was then the fledgling discipline of Melville studies are now well known, nor was he reluctant to be his own advocate. A case in point is a letter to Merton M. Sealts Jr., in which he demands rhetorically, "who 1st emphasized this 'role of books'," i.e., the part played by Melville's prodigious reading in his craft of writing. Olson replies that he himself deserves this honor and tells Sealts to "cf. Olson MA thesis, Wesleyan-Yale, 1933"-a thesis that begins with what its young author calls "the first complete bibliography of Herman Melville ever attempted" (Sealts 1982, p. 109; Olson 1933, p. i). By that time he had likely transcribed all the marginalia in all the books that Eleanor Melville Metcalfe, then his close friend, almost his adoptive parent, had inherited from her grandfather. The next winter he and a friend went to see Frances Osborne, another granddaughter, who entrusted him with almost 100 more of Melville's books, including his prized seven-volume set of Shakespeare's Plays.

Olson's recovery of the Shakespeares has been narrated as a Eureka moment. Melville had, in one of his most memorable letters, described the very volumes that Olson now held in his hands. As Ralph Maud says: "Little could Olson have expected to discover this same seven-volume Shakespeare; but in a triumph beyond any young scholar's dreams, he did" (Maud 2008, p. 34). Stephen Collis, listening to Maud's rehearsal of this story in 2009, seems to respond with breathless awe: "the goldmine" (Maud 2009, p. 35). Even more consequential, according to most accounts, was something he found on the last rear flyleaf of the last volume. Melville had written down the words of a Latin formula, then another five lines of notes that seemed to comment on it:

Ego non baptizo te in nominee Patris et

Filii et Spiritus Sancti — sed in nomine

Diaboli. - Madness is undefinable -

It \& right reason extremes of one.

-Not the [inserted later above line with caret below (black art)] Goetic

but Theurgic magic -

seeks converse with the Intelligence, Power, the

Angel. ${ }^{16}$

The Latin, (minus "et | Filii et Spiritus Sancti"), Ahab "howls" in Chapter 113 of Moby-Dick, "The Forge" (Melville 1988, p. 489). Melville, to Hawthorne, said that this blasphemously inverted baptismal formula was none other than the secret "motto" of the whole book (Melville 1993, p. 196). "We can imagine", writes Geoffrey Sanborn, with perceptible sarcasm, "Olson's reaction" to what he had found (Sanborn 1992, p. 213). The fact that Melville had used his Shakespeare-and not just any of the volumes, but the very last, and specifically the last blank page of the last volume-as the place to write out this inscription suggested what he was doing in Moby-Dick. He was going to pick up where Shakespeare's oeuvre ends, to begin again with what was underway in the Plays, but as yet still unaccomplished in the present.

Olson's first major publication, "Lear and Moby-Dick", argues on this basis that Melville was attracted to Shakespeare's "darkness", his fascination with "Madness, villainy and evil" - themes of which he was, nonetheless, incapable of speaking openly. Olson's Melville writes outwardly of what, supposedly, Shakespeare could or would not, an infernal nexus of diabolism and tyranny that

16 Melville 1988, p. 970. See Melville 2009, pp. 905-16, for up-to-date discussion. 
is triumphally overcome in the working out of a "democratic prose tragedy" (Olson 1992, pp. 268, 283). Olson invests even more significance in the flyleaf notes in Call Me Ishmael. But, this time, he does not side with the Melville who wrote a "democratic prose tragedy". Instead, he aligns his own self-formation as a poet with the recovery of what fell away when Moby-Dick ended. What was lost was, Olson argues, the real basis of Melville's affinity with Shakespeare: his preternatural attunement to conditions of darkness, fallenness, disaffection, and inhumanity. It is this dark side of his authorship that Olson, writing after World War II and in the shadow of the nuclear threat, takes to be the background against which his own poetry was to be written.

It is to the so-called "rough notes for the composition of Moby-Dick" (Olson 1997, p. 42), that Olson seems to allude on p. 66 of Ace of Pentacles. In the bottom left corner in a compressed script, are two upward-slanting lines of writing, both underscored, the second with what looks a long dash in front of it (see Figure 4, below). Olson seems to have written: "like Melville - - on the leaf of Shakespeare", as though comparing his annotations to those his favorite writer had once inscribed at the back of the Plays:

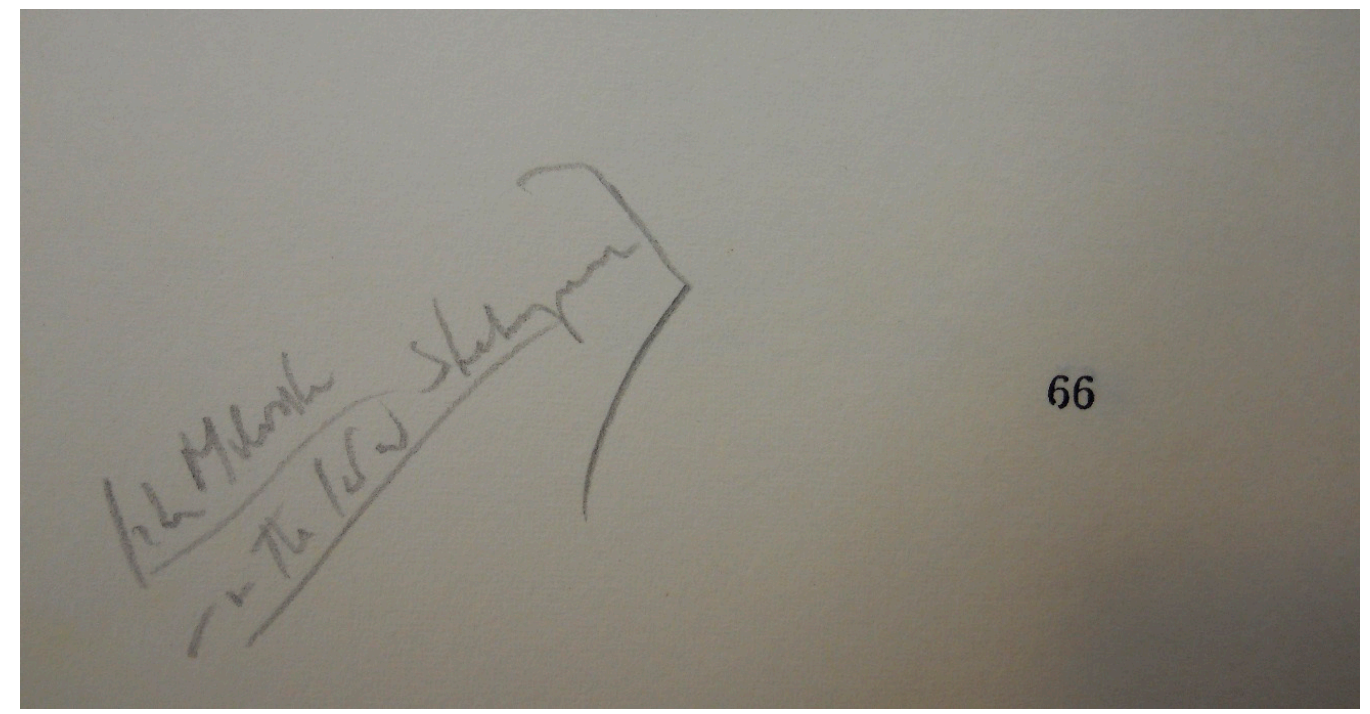

Figure 4. Page 66 of "Manuscript. Written on 'Ace of Pentacles' by John Wieners", box 24, folder 1147, CORC.

Olson clearly, then, took his marginalia to Ace of Pentacles very seriously. Was Wieners, in some sense, his Shakespeare, at that point in his life?

In what follows I attempt to think through this question, but not by trying to follow in Olson's footsteps. Instead, I want to take issue with what I have called the Eureka story of his recovering the annotated Shakespeare set. Olson's immediate reaction was not to rush with his discovery into print. A few months later, scouring New York for more of the books that Melville had formerly owned and used, he wrote down an account of his graveside visit to his hero's last resting place, in the vast grounds of Woodlawn Cemetery in the Bronx. "I made my pilgrimage to Melville's grave today", writes the young Olson; "it was a sobering experience".

I yearned overwhelmingly to throw myself on the grass over his body when I should get to him. It gave me deep pause, then, to find no grass beneath his stone, only a bristling, close-cropped, forbidding ivy covering the bare ground over his body-and that ivy dead to leafless save a few eaten \& wrinkled ones of another year. Even nature seemed ready to challenge my presumption in hoping to come close to Herman Melville. It was chastening to be so near his bones and the dust of his bones and be no closer. I proposed to uncover his mind and soul quite as ruthlessly from the grave of his books and letters as though (like a 
Jerry Cruncher) I had struck a spade into the soft turf there this afternoon [ ... ] God how I was humbled. ${ }^{17}$

This reprises, in part, an accusation he had levelled at "the scholars" in his MA thesis. The "crassness of Jerry Cruncher" was, he felt, endemic to academic specialists who fetishize unpublished remains, secrets of the archive (Olson 1933, p. 8). His notebook entry melodramatically rehearses this aversion, but also indicates genuine unease with what he was then doing. Amid his transcriptions of all the marginalia Melville wrote inside of his Shakespeare, Olson has given vent to countless expressions of bafflement and dismay. Arguably, the very fullness of meaning he imputes in Ishmael to the annotated flyleaf is determined by how little he gleaned from many of the other markings Melville had written, which obdurately resisted his attempts to extract meaning from them. The first prolonged study Olson made of the marginalia did not, then, deliver an infallible heuristic key into his hands; on the contrary, he often despaired of their indeterminacy and inscrutability. ${ }^{18}$

It may be the Olson of the transcriptions, not of Ishmael, we need to remember as we examine his Ace of Pentacles. Floating near the bottom of p. 31 we find this inscription: "for Marion- |-Shakespeare". This obviously references "For Marion", the poem six pages back of where he is now writing, but what he means is not clear at all. The mystery has no obvious solution. I see no reason why "For Marion" would remind him of Shakespeare, nor is there anything to this effect in the marginalia he wrote beside it. There is, off in the left margin, this two-line note: "The study | of poetry". Olson said unequivocally that "Melville studied Shakespeare's craft" (Olson 1997, p. 61), and perhaps he thought "For Marion" exhibited Wieners' studied mastery of craftsmanship to its maximal advantage, a mastery it behooved him to "study" as Melville did Shakespeare's—but this is all conjecture, only illustrative of how hard it is to know what motivates so many of Olson's markings. It is no use, then, to seek a perfect analogy between the Melville-Shakespeare affinity, as he represents it in Ishmael, and the nature of the bond he had with Wieners. But nor can we simply ignore or forget the question of why he felt he was "like Melville" as he wrote his way through Ace of Pentacles.

Olson's annotations are, in his own reckoning, "considered to follow" two additional sets of notes, now very hard to reconstitute. ${ }^{19}$ Were we in possession of all the notes, however, other problems would persist. It is clear that Olson's inscriptions in Ace of Pentacles implicate other notes and fragments besides

17 This entry is in the unpaginated journal called “N.Y. City. No. 26. May 6, 1934-1936”, box 49, CORC. See Melville 2018, p. 91, for a photo of the grave taken in 1951. Cf. also "Letter for Melville, 1951" (Olson 1987, pp. 233-41).

18 See, e.g., the following comments he wrote amid his transcriptions from Melville's volumes of Shakespeare (numbers are those assigned by CORC to each of the file cards on which the transcriptions are written). Olson finds "No pattern \& chaos" to Melville's annotations in The Winter's Tale: "Whatever suits his fancy he marks" (Olson 2004, Card 348). Other markings

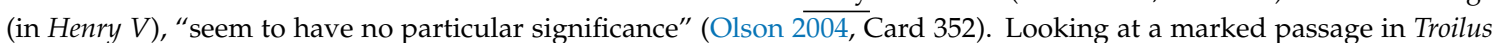
and Cressida, Olson writes "why this struck Melville is slightly difficult to see" (Olson 2004, Card 422). Likewise, to his chagrin, "No pattern results from M's marks" in Julius Caesar (Olson 2004, Card 418). There's "Nothing outstanding" about his markings in Cymbeline (Olson 2004, Card 410). Sometimes, Melville does not mark the passages Olson assumes would interest him: "On 448 is the sc. of Act II [in Pericles] with the 3 Fishermen talking of porpoises and whales and yet there's not a breath out of HM!" (Olson 2004, Card 412). He is astonished that “H.M should get no more out of R \& J!", i.e., Romeo and Juliet (Olson 2004, Card 824). At one point he wagers that "when Melville was most moved by the play he was least moved to write", only to instance other notes that contradict this all-too-ingenious idea (Olson 2004, Card 389). Olson was exasperated by anomalous and erased markings: "This is a peculiar mark"; “This mark of Melville's has been partially erased-why, why?" (Olson 2004, Card 412). He fared better with what he found in King Lear, Timon of Athens, Antony and Cleopatra, and (to a lesser degree) The Tempest. Still, only a very small fraction of all he transcribed from the Shakespeares is ever discussed in "Lear and Moby-Dick" or Ishmael.

19 In box 91, folder 141, containing materials from 1964, there is a pocket-sized card showing a nightly chef's special (Chili Con Carne with French Bread and Butter, 50థ) with notes by Olson on the front and back. Some of the notes call to mind his annotations in Ace of Pentacles. On one side of the card he has written the words: "Pure. straight. true. Real", and underneath the untitled poem on p. 34 he describes Betty Kaiser as “Quiet. Straight. All There: 'Clean'”. On the other side of the card there is what looks like a poem:

Hollowed out eyes

of suffering, burnt out sockets in the skull

from pain

Compare the first stanza of "Two Years Later", the last poem in Ace of Pentacles (not marked by Olson): 
those he specifies on its front flyleaf. Availing ourselves of this material compensates, in some measure, for what has not been found, but also widens the latitude for misinterpretation. A working distinction can be made between drafts or outlines for essays and poems, and the mass of less differentiated types of text material in Olson's archive. To step outside the focal point of interest provided by a published poem or prose work is to enter unbounded territory, where any piece of written text can be reconceived as a nodal point in a cluster of interrelated fragments, textual constellations of uncertain extent. A ruthlessly systematic search of his archive could presumably identify every last piece of evidence bearing on the annotations and their meaning. But then, some parts of his papers remain closed, including at least one journal written in 1964. Lastly, there is no guarantee that a given marginal note is unrelated to documents that no longer survive: ephemeral materials in his archive are part of a textual continuum that extends into the abyss of lost and destroyed writing.

In the last book of The Maximus Poems, Olson writes that

... There is a vast

internal life, a sea or organism

full of sounds \& memoried

objects swimming or sunk

in the great fall of it ... (Olson 1983, p. 573)

Olson's late poems and Olson's papers both give a sense of this "vast | internal life"-layers of overlapping textual traces, "memoried objects" swimming in a poetic space of associational crosscurrents and distorted echoes. Instead of comprehensively surveying everything he wrote inside Ace of Pentacles, I want to follow some of these echoes and object-traces as they circulate through the marginalia and turn up elsewhere, not only in the typescript poems, but in other notes and papers and in some of his published poetry. The metaphor of circulation is important in that I make no pretense of knowing what follows what, neither the order in which the markings were made, nor the typescripts written, nor the peripheral materials produced. This is not, in other words, a genetic analysis of any kind, even if what follows sometimes takes narrative form. Instead, I will argue that Olson found some form of consolation, if not closure, in Ace of Pentacles, that helped him work through the implications of his wife's death. My approach will be to follow a few simple words-"belief", "power", and "color", primarily-into and out of the marginalia, unfolding some of their resonance for The Maximus Poems, but without claiming to exhaust the range of meanings Olson ascribed to them. ${ }^{20}$

\section{Consoler}

What kind of a book is Ace of Pentacles? On Wednesday, October 14, Olson wrote a tortured twelve pages of notes, full of self-vituperative angst and sorrow. But, at one point, he seems to catch himself and to write a reference, a "cf.", which reads like a reminder to keep his composure, to hang on and not fall off:

$$
\begin{aligned}
& \text { cf. John } \\
& \text { (Wieners) poem } \\
& \text { in Poems Called—why?_Ace(s) of }
\end{aligned}
$$

\footnotetext{
The hollow eyes of shock remain

Electric sockets burnt out in the skull.
}

The marked-up card, then, would be an obvious candidate for the "pocket notes", those he had "written at Town \& Country restaurant | Wednesday", though there's no guarantee that this is all he wrote there, and that other scraps of paper have not been misplaced. I have not been able to identify his "notes Thursday night".

20 On the need to find ways of reading Olson's archive, see Friedlander 2007, pp. viii-ix; and Byrd 2013, pp. 84-110, for an approach that differs from mine. 
Pentacles) on

Strung on a line \& definitely Don't

$\underline{\text { Fall Off }}^{21}$

Why, to answer his question, did Wieners settle on this title? In January of 1964, he had sent the book's publisher a list of possible titles. "But", he adds, "PENTACLE is the one I really favor want. It has an excellent definition in any dictionary: the pent (five) and the acle from OSCULUM-OSCULUS-dim-five dim (years-from 1958-1963 when the majority of poems were written" (Stewart 2014, p. 332). Wieners had been through five very dim years indeed, surviving poverty and itineracy, substance abuse and heroin addiction, plus two harrowing incarcerations in what Maria Damon has called "the Matrix of Massachusetts Institutions"-psychiatric hospitals where the treatments administered seem only to have compounded whatever cognitive damage he had suffered already (Damon 2014, p. 69). Ace of Pentacles, written in the wake of destitution, addiction, and imprisonment, is nothing if not a book of anguished remembrances, dark hours, blighted days, and recovery from trauma. Olson's memory of something to the effect of "Strung on a line \& definitely

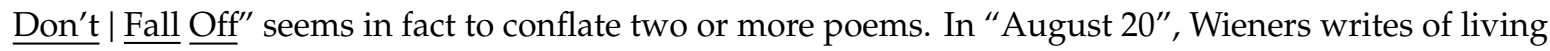
a fragilely overstretched life:

It is as if life were stretched upon a rod and we no choice to make but spare the self, lord, from falling off that high wire. ${ }^{22}$

These lines could have come back to Olson as a precise expression of his own feelings at the time. It is likely that on the night of October 9, he found some form of "Consolation" in Ace of Pentacles that helped him toward some provisional form of equilibrium. Arguably, he says as much in the left margin of the untitled poem on p. 24:

Let the heart's pain slack off

To that secret place we go to in time

$\rightarrow$ Without rhyme's safety to assure us,

All gift is, that perfect joy. Some sign.

$\overline{\text { Smoke rising from parapets of glass. }}$

No book I turn to but I hear

An inner voice so dear say

"Pass over the commands today; forget

What is allowed, and what is not.

What youth has got. The bizarre symptoms

Of yesterday. The past equal to now."' [sic]

No words here fit for print, no worlds either disclose themselves, just debris solid enough to erect a wall against parapet all mentioned above; open only like doors to love.

Consolation-cons

21 Unsorted manuscripts and fragments (1964), box 91, folder 149, CORC. The word I have transcribed as "definitely" is hard to read and could conceivably be "determinedly" or something else.

22 Wieners 1964, p. 48. Olson has not marked this passage. 
soler

Wieners was to play the role of consoler in person after he arrived in Buffalo for the winter semester of 1964-1965. In the spring, Olson wrote to Dorn that: "if John hadn't been here I'm sure I'd have come to grief. He is a comfort like the Irish say and besides his poems wow me" (Olson 2000b, p. 324). Relief from pain is a constant subject in Ace of Pentacles. Yet the top two lines of the poem above suggest more than one reading. Is it that we go "in time" to a secret place where pain slackens, and the heart is healed? Or that pain, as though of its own volition, absconds to a "secret place" where, nonetheless, we are destined to someday join it-perhaps even to live with it in peace? The rhythm and music of the first two lines, however, seems to involve a kind of grammar that is too "weak" to support multiple levels of meaning (see Sutherland 2012). Olson's eye alights on the evocation of wall-building and aligns it with the glassy "parapet" of line four. Is the secret redoubt that delivers relief from pain, then, bound by a "wall" and protected by parapets? It is one motivation of The Maximus Poems to "build out of sound the walls of the city", recasting the precincts of Gloucester after the image of an ancient temenos (Olson 1983, p. 600). Still, Olson's underlinings in the last stanza of the poem above suggest another environing enclosure- that of the book wherein he is writing, not anything "fit for print", but simply the traces of his passage through it.

The question, then, is where Olson's markings were to take him. Consider what he writes about the poem called "For Marion", in the bottom left corner below it:

[the lovely addressing to

Women-as Louise etc.

-as though any woman

could be chosen-or place

(Waltham) from provocation (having) from

song. pain. rhyme.

('s

safety

Near the end of Ace of Pentacles there is a poem called "Address to the Woman". There is also a poem "For Jan", besides the one "For Marion", and Olson also alludes to the poem called "Louise", on p. 20. A sense of what he means by "addressing to / Women" can perhaps be gained from his review of Creeley's For Love: Poems 1950-1960, written in 1962. Creeley, Olson says, tries to tell us exactly what "he has to show for what he has lived". He does so, usually, very "wryly-except when he does address himself to the woman he loves then, and she is what makes life otherwise possible" (Olson 1997, p 285). When Byrd says that, after Betty Kaiser died, Olson wrote "a sequence of poems addressed to her", he may have this widened sense of "address" in mind. The "sequence" (if this it be) is not so much addressed to her, as though tacitly premised on the fiction of her listening presence, as it is an effort to "address himself to the woman he loves" and to address the nature of this love-to disclose to himself what "he has to show for what he has lived" through, and perhaps to find means therein of making life "possible" again.

An address can be a "place", and this word, written where it is, takes on overtones of allusion to "the secret place" of the previous page. Another "place" is the Waltham of "The Windows of Waltham", one of two short poems on p. 23:

\section{THE WINDOWS OF WALTHAM}

Sol, Bronze Age came first Sol,

Wong, before snow nothing came.

Dont worry about the wisdom of

the past.

Two met and made a first. 
Underneath and to the left of this poem, Olson has written "Love's | sung" and then "love's | singer", presumably in praise of his old friend as a consummate singer of love songs. In the right margin of "For Marion" he calls Wieners "love's Eumolpidae", as though there were something he had in common with Demeter's priests at Eleusis. When, in "The Mermaid's Song", Wieners writes, "If this be said I loved with all my worth", Olson underlines the last four words and adds, as his own comment, "Eumolpidae" in the margin. In the second volume of The Maximus Poems, he had written:

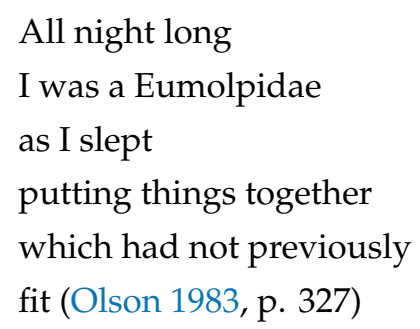

The culture hero Eumolpus has a name that means "sweet singer", and Jane Harrison, in a book Olson owned and read, says that sweetness and resonance of voice were requisite attributes of the hierophant, summoner of the celebrants to the Eleusinian cavern. ${ }^{23}$ Wieners, if not his Shakespeare, may have been Olson's hierophant, calling him down to unvisited parts of his own consciousness, from which he wrote his handful of "poems on Bet". It is the making of these poems that we now need to investigate.

\section{Vita Nova}

When news came to J.H. Prynne of the car accident of March 28, he dispatched a letter of condolence to Olson at once:

\section{Dear Charles,}

I have just heard of it, from Jonathan. A terrible thing. I do not presume to "say" anything, but the ensuing silence is all for yourself. Passengers, ex illo tempore.

$$
\begin{aligned}
& \text { As always, } \\
& \text { Jeremy (Olson and Prynne 2017, p. 93) }
\end{aligned}
$$

The words "ex illo tempore" echo an expression used incessantly by Mircea Eliade, especially in Myths, Dreams, and Mysteries, a book Prynne may already have had on his desk. It was not long until he had read all of it and sent Olson an account of its contents, plus an extract from its preface. A myth, argues Eliade, is not a fiction. It is, instead, a narration of what "really happened" in times gone by, and what still holds true in the present. Eliade's sense of myth is close to what Olson's beloved Jane Harrison had written in Ancient Art and Ritual about rites and their performance: "The Greek word for a rite [ ... ] is dromenon", meaning "a thing done" (Harrison 1913, p. 35). A myth, for both, is a saying that is also a doing, an incarnation of what happened, as Eliade writes, "in illo tempore" - the "holy era of the beginning", when gods and men lived on the same plane of being, and the cosmos took form from their actions. "Myths", he argues, "reveal the structure of reality and the multiple modalities of being in the world"; each is "exemplary", founding archetypal patterns for human behavior (Eliade 1960, pp. 14-15). In Prynne's paraphrase of Eliade, myths "afford a world and the rhythms for living in it" (Olson and Prynne 2017, p. 95).

Olson, fascinated, picked up his own copy of Myths, Dreams, and Mysteries, ${ }^{24}$ dating not only his acquisition of the book, but also his reading of it:

23 Harrison 1890, p. lv; see Butterick 1978, p. 449.

24 CORC class mark Olson 576 


\begin{tabular}{|c|c|c|}
\hline & Charles' & \\
\hline$b c$ & $\begin{array}{l}\text { April-May } \\
1964\end{array}$ & $\begin{array}{l}\text { alone with Charles Peter } \\
\text { read 1st week June } \\
1964 \text { Wyoming }\end{array}$ \\
\hline
\end{tabular}

These notes are planted in the middle of a long prose meditation, written in pencil, that fills up the rest of the page, and also half of the next. Olson, at one point, asks himself a question, which he underlines: "How can one do anything but be extremely careful to believe in the extraordinary 'power' locked up in oneself"? Yet, what care can be taken to ensure that one believes? Olson answers:

Believe, by having the unsupported confidence non-conditional confidence of my own

$\begin{array}{ll} & \text { Year } \\ \text { Go to your words } & \text { Paradise } \\ & \text { process } \\ & \text { reality }\end{array}$

Whitehead's Process and Reality had long been a touchstone for Olson. But what about the words "Year" and "Paradise"? Eliade argues that traces of archaic rituals persist down the ages, wanly surviving in "certain festivals observed in the modern world":

The rejoicings over the New Year, or the festivities following the birth of a child, or the building of a house, or even the removal into a new flat, show the obscurely felt need for an entirely new beginning, of an incipit vita nova-that is, of a complete regeneration. Remote as these profane rejoicings may be from their mythic archetype-the periodic repetition of the creation - it is none the less evident that modern man still feels the need for periodic re-enactments of such scenarios, however secularized they have become. (p. 28)

By this paragraph, Olson has written, 'It is my Year', as though he had, in his own life, come to the moment when profane and sacred time momentarily intersect or overlap. But, asks Eliade, if the life of myth has, in effect, migrated into wholly secular pastimes, does this not attest to a profound disenchantment of the world? If even the mythical is desacralized, what place is left for its role of setting up "exemplary" patterns of behavior, paradigmatic ways of being?

Eliade's answer, that Christianity shelters the afterlife of myth, was not to Olson's liking. It is, he argues, ultimately the hallowed dates of the liturgical calendar alone that deserve comparison to age-old rites of welcoming the year. But, he hastens to add, Christianity has "nothing to fear from such a comparison: its specificity is assured, it is guaranteed by faith as the category sui generis of religious experience, and by its valorisation in history" (p. 29). Olson marks this last phrase with an X on each side, and registers his disagreement below it:

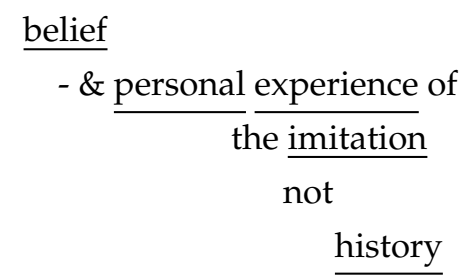


It is not, then, upon Christianity, nor its promise of redemption in history, that myth depends for its survival. Olson's heart is swayed by an antinomian belief in the efficacy of "personal experience" to light the way to exemplary patterns of being. Not an imitatio Christi, then, but only arduous self-imitation, conducted across inner distances, has any chance of unlocking the restorative plenitude secreted in the old rites of yearly renewal.

The turn of the year holds out the promise of "an incipit vita nova". Olson had used the last two words (except in Italian) in "La Préface", denying that life could really begin anew again in the aftermath of World War II and its masses of dead:

The dead in via

in vita nuova,

in the way. (Olson 1987, p. 46)

The dead are there, in the way, where we go looking for new life. Olson is also referring indirectly to Dante's Vita Nova, its dream of a love that transfigures and redeems, and the European world that embraced this dream. But, in the poem that Olson wrote on the back of Ace of Pentacles, she who "was killed", her death, eclipses, for him, any hope of regaining "new life", vita nova:

I went full tilt

And then she was killed,

in her automobile

I need every bleeding minute now

I don't have any time for any new life

In "La Préface", the ruined world demands the use of commensurately pared-down formal means-a radical starting-over with primitive language-implements, as simple as a nail, a sliver of bone, or a stick of wood. A world reduced to primeval beginnings holds out the promise of a possible renewal, re-attunement to elemental messages and first things. Olson's use of the phrase "I went full tilt" demarcates the point at which an idiom starts to sound hieratic and lapidary, vatic in its simplicity. Witness its appearance in a poem he wrote a year before, in May or June of 1963:

His house

in the branches of

Iggdrasil

the coral plant

on the bottom of the

pool by the rock I was levered over full tilt

to watch a very small crab make

the good sized mussel wave

in the water while

on a rock in the water busy

barnacles were opening the slit in their horned eye (Olson 1975b, p. 30) 
In this poem, to be "levered over full tilt" means to bring a miniature cosmos, a microcosm of the vast ocean, to a condition of fullness and repletion, environing and sealing it in from above. Conversely, when Olson says that he "went full tilt | and then she was killed", there is no trace of mythical self-elevation. Approximately one year before the accident, he wrote a poem that memorializes an ancient system of timekeeping. "A century or two before 2000 | BC", he says, "the year rebegan in March" (Olson 1983, p. 333). In a taped interview, conducted in 1968, he is more precise: there was an old "calendar in which the year began - the new year was March 28th, if I'm not mistaken-so that the first month of the year was March" (Olson 2010, p. 296). This was, of course, the very day on which Betty Kaiser lost her life-March 28, 1964, the Saturday before Easter Sunday. Olson, four years from the accident, aligns his wife's death with the conjuncture of sacred and profane time that Eliade had marked out as the specific province of myth. What, then, does this mean for the syncretic mythical architecture of The Maximus Poems?

Olson had beseeched himself to "Believe", by having "unsupported confidence" and "nonconditional confidence". On October 3rd he wrote a poem that begins with this line: "you better believe in your self" ("Annex II: Rejected Poems", Butterick 1983, p. 7). Back in class, he said more about what he means by the word "belief": "you must", he told his students, "discover your 'leading propensity', your own unique stamp or type as a person, and this requires courage and belief on your part" (Clarke 2016, p. 127). On an envelope enclosing a letter to Albert Glover, dated October 7th, 1965, he insists that a thought, any thought, is only interesting "when it has already produced belief (that is, in the person 'thinking') so that the 'thought' in effect is already action" (Maud 1996, p. 172), an argument he attributes to Charles Peirce. Olson was to repeat the same thing to Ann Charters in 1968: "The soul and meaning of thought" is none other than "the production of belief" (Charters and Olson 2015, p. 83). But, the sources of his own self-belief were fractured by the accident of March 28. Olson, in notes written on June 13, seems to yearn for "Confidence in my Subjective (primordial) | Construct", so that, in his words, subjectivity no longer "stops" where the "objective" begins, as though feebly slumping away from it. Olson complains of lacking "the morality to supply con | fidences (therefore con man". ${ }^{25}$ The words in the unclosed parenthesis call to mind the title of Melville's The Confidence-Man, a book that fascinated and repelled him. "THE CONFIDENCE MAN is CHRIST" he had declared in 1950, seconding Ishmael, which is just as unequivocal (Olson 1999, p. 16): "In The Confidence-Man", Melville "used Christ himself directly as a character" (Olson 1997, p. 91). In Olson's language, "confidence" is shadowed by "faith" of the kind Eliade associates with devotional imitation, self-approximation to an external model of perfection. His rejoinder had been to emphasize self-belief over faith-but how, on the verge of despair, to regain belief in oneself?

Olson, writes Ralph Maud, "once said that his greatest satisfaction was when he came close to writing down his dreams". ${ }^{26}$ He may have had in mind this paragraph from one of Olson's letters to Rumaker: "the hardest form, I suppose, to force writing to undo, and recreate on its own", is "the dream-form". This means the "reanimated" dream, recast as a poem, is the most perfect of forms (Olson 2000b, p. 246). Hence Olson called "The Librarian" the "best poem I ever wrote" on account of its near-perfect approximation of the intense inwardness that belongs to dreams (Olson 2010, p. 205). In the later part of his life, one dream in particular had a profound effect on him. It is to this dream that Butterick alludes when, in Editing The Maximus Poems, he embarks on a discussion of one of the poems he had decided to exclude from the sequence, despite its being called "A Maximus". This rejected poem, in its entirety, reads as follows:

A Maximus:

Kingson, Kings-

25 Unsorted manuscripts and fragments (1964), box 91, folder 146, CORC.

26 Maud 1976, p. 34. See Fredman 2013, p. 26: "not enough has been made [ .. ] of Olson's extensive dream work". 
ton

King(s)son Kings-

(s)ton

Wednesday October 24th 1964 (“Annex II: Rejected Poems”, Butterick 1983, p. 10)

"Probably", Butterick writes, "there is a very private reference to Kingston, N.Y., possibly even as a detail from a dream (the name occurs, perhaps for the first time, in a scribbled note concerning the poet's wife's colorful dress" (Butterick 1983, p. xiii). This scribbled note has the look of a poem and records a dream in which he sees his wife wearing a colorful dress and hears her voice speaking to him:

\section{Elizabeth \\ Olson wife of my}

In Kingston, Bet the dream said

What "the dream said" is at times nonsensical and absurd. Olson hears himself, bizarrely, remarking that "you smelled like you"; but what he recalls hearing her say to him is resonant and profound:

if I followed you

into the colors of your own dress (it said)

in Kingston (!) it said

oh up the definitely ladder

my beloved I shall

for you (it said) $)^{27}$

He does not say what is to come should he follow as he is directed, nor how entry into "colors" could be obtained. Nor is it clear how the ladder comes on the scene, nor what his fervent assent means to him, or to her. Olson's memory of this dream, however, of the ladder, the colorful dress, and the place-name, Kingston, was to haunt him for a long time and, as we will see, influence his reading of Ace of Pentacles.

Of all the poetry Wieners had written, Olson was most impressed by one poem in particular: "The Acts of Youth" (Olson and Wieners 2012, vol. 2, p. 42). The poem turns around a central pivot-point, moving from anguish and despair to ecstatic hopefulness. The basis of this transition is the glimmer of the possibility that even the most unbearable of experiences may be, in some higher reckoning, an enabling condition of "great art". "Do not think of the future", Wieners writes, "there is none. | But the formula all great art is made of":

Pain and suffering. Give me the strength

to bear it, to enter those places where the

great animals are caged. And we can live

at peace by their side. A bride to the burden

that no god imposes but knows we have the means

to sustain its force unto the end of our days.

For that it is what we are made for; for that

we are created. Until the dark hours are done.

27 Unsorted manuscripts and fragments (1964), box 91, folder 149, CORC. 
The underlinings Olson has made all point in the same direction, toward the hope of attaining communion with an infallibly efficacious "power of life". Two pages later, in the page space under "An Anniversary of Death", he writes impassionedly of:

[John's

power of life: the means to sustain its force

unto the end of our days, what we are made for,

for what we are created-

["Until the dark hours are done"

Could this be the "power" of which he had written in Eliade's book - "the extraordinary power locked up in oneself" that restores unshakable self-belief? The two words "force" and "power" come up over and over in his notes, as though holding their secrets just out of his reach. Olson's pursuit of this "power of life" however, seems to bring him to the details of the dream he had, presumably, recently had about his wife and her colorful dress. A précis of this dream and its main elements appears in the page space below "The Acts of Youth", on p. 29:

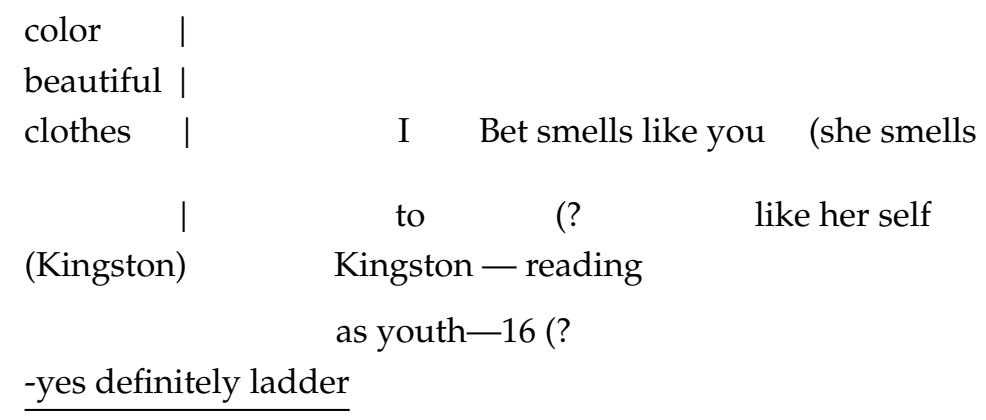

It is at this point that his markings diverge mostly clearly in character from those he had found in Melville's Shakespeare set. Whereas most of those inscriptions were in some way focused, albeit often obliquely or confusingly, on the main text, Olson's additions to Ace of Pentacles form part of a textual continuum that extends outside the book in which he is writing. The next element of this continuum we need to consider is the oversized, spiral-bound sketchbook he was then using for notes, now filed under the name of "Notebook. No. 150. October 1964-December 1964".

If Olson was puzzled by his eerie dream, he may have turned to C.G. Jung's Psychology and Alchemy in the hope of interpreting it. ${ }^{28}$ In his big sketchbook, he has written the following:

Round is lead chaos rotundum

bodhisattva

-magical quest the cosmic source of energy

124

Studies

the cosmic source

And Dreams. Vision

of energy

the self

the slow lazy secluded

self

the most natural \& perfect work is to produce

28 Jung 1953 (This is the edition Olson owned and used). Part II (pp. 47-213) is a long analysis of over fifty dreams, full of esoteric images. Jung instances one dream in which there is a rainbow bridge (pp. 56-7, 60,109) and another with "many ladders" (p. 61). 


\section{that which is like to its self}

In old alchemical books, Jung says, the rotundum, an inky black orb, stands for incoherence and "chaos", as heavy, dark, and dense as lead (Jung 1953, p. 324). Olson is, however, on p. 124 of Psychology and Alchemy, where there is an account of the iconography of the mandala, said to represent an articulated and fully realized form of individuality. Jung recognizes the involutions of the mandala-form in the organization of sacred buildings and holy sites, where a central space is marked out for a "Holy of Holies, with its magical agent, the cosmic source of energy, be it the god Shiva, the Buddha, [or] a bodhisattva".

Later, Jung cites an old alchemical motto: "The most natural and perfect work is to generate its like" (p. 213), which Olson alters only slightly: "the most natural \& perfect work is to produce | that which is like to its self". In the annals of alchemy, this motto, that perfection generates its like, is associated with a totemic animal - the peacock and its gloriously shining tail, the cauda pavonis. In the tail, all colors come together: it is, Jung says, a resplendent "combination of all colors, symbolizing wholeness". On another page of his notebook (Figure 5), Olson writes a line of prose, and then, begins a poem (the first stanza has an emphatic " $X$ " drawn over it):

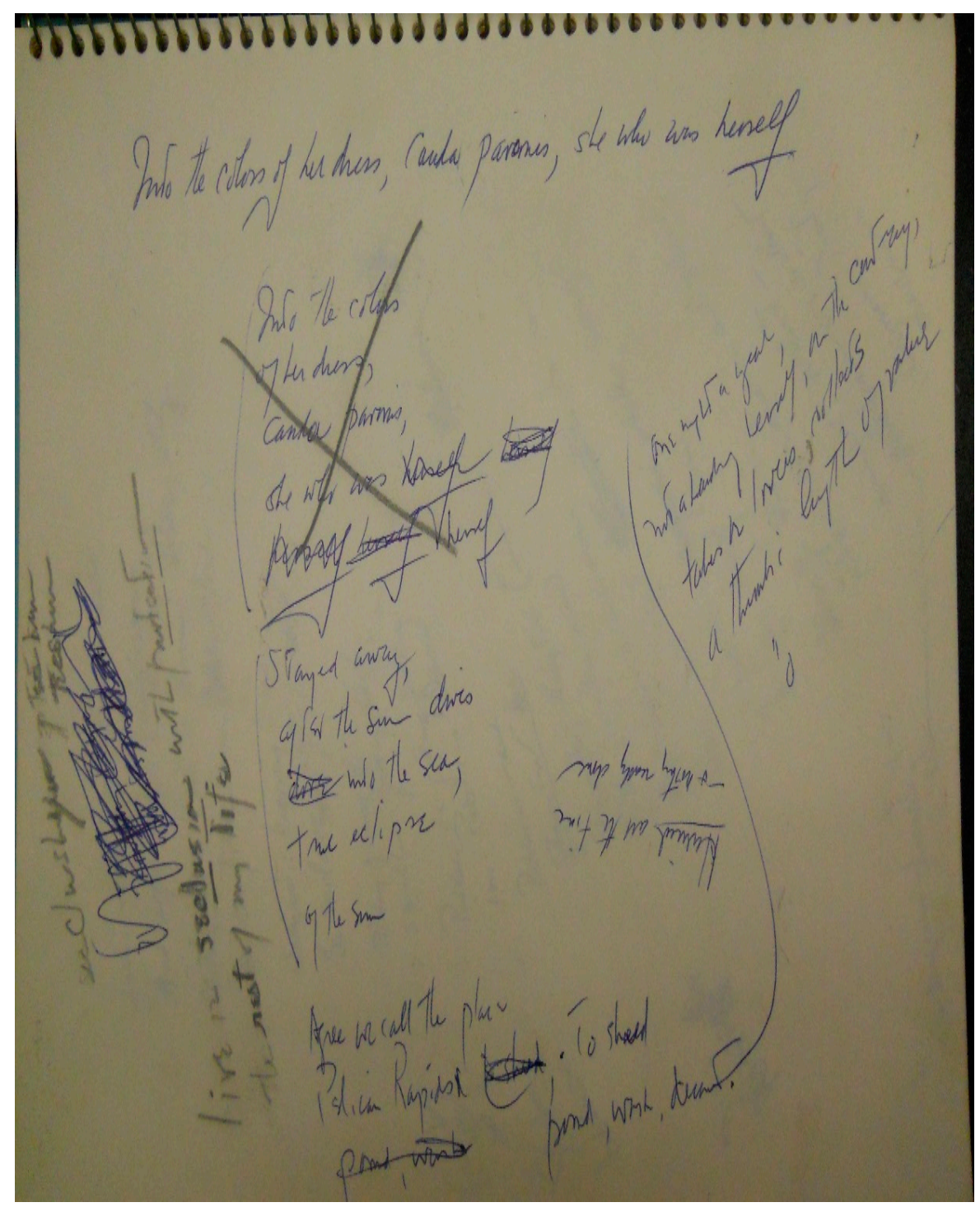

Figure 5. Page from "Notebook. No. 150. October 1964-December 1964", box 65, CORC. My transcription omits the side-notes to the left (to which we will return) and also the two upside-down lines mid-page. 
Into the colors of her dress, cauda pavonis, she who was herself

Into the colors

of her dress,

cauda pavonis,

she who was herself herself

herself herself herself

Stayed away,

after the sun dives

dove into the sea,

true eclipse

of the sun

Agree we call the place

Pelican Rapids to shred. To shred

pound, wash pound, wash, decant.

one night a year

not abandoning herself, on the contrary,

takes on lovers, collects

a thumb's length of value

Olson's poem is written in dialogue with Jung. The second stanza is based on his interpretation of a grotesque engraving that depicts, allegorically, the stages of the alchemical process. On one tier of this illustration, Jung says, we see the following:

The sun diving into the sea, i.e., into the Mercurial water into which the elixir also must flow. This leads to the true eclipse of the sun, and one should put a rainbow on either side to suggest the peacock's tail that then appears in the coagulation. (p. 274)

Olson then turns his back on Jung's text. The next stanza reiterates, almost verbatim, the words of a poem he had written no fewer than 14 years before, "The She-Bear" (Olson 1987, pp. 129-43). In the various renditions and iterations of this older poem, we find these two lines, "To shred, pound, wash, decant" and "Agree we call the place | Pelican rapids" (pp. 129, 131), as well as this passage:

one night a year the priestess,

not abandoning herself,

on the contrary

by presentation takes on lovers

collects

a thumb's length of value (coins,

or turquoise pieces), leaves them (pp. 130-31)

"The She-Bear", we know, was a product of Olson's relationship with the book designer and independent scholar, Frances Boldereff, who stimulated his interest in the archaic. In her analysis of their correspondence, Rachel Blau DuPlessis criticizes his investment in the viciously patriarchal terms of Jung's archetypal psychology. "The She-Bear", she argues, is an "overeager, undistinguished poem", disfigured by sex/gender contradictions embedded in its apostrophic form. This would-be praise song "consists of pages of apostrophes (o this, or that) to avatar forms of the Great Goddess (Jung links the she-bear to Artemis)" (DuPlessis 2012, p. 136). In 1964, then, Olson once more takes up the strains of "The She-Bear", while excising all trace of Artemis and her priestess, now supplanted by the 
prismatic cauda pavonis and its attenuated wisp of a connection back to Betty Kaiser, the real-life person he is mourning.

Olson's judgment on this experiment was ruthlessly severe. By crossing the first stanza out, he severs the connection he had drawn between his current predicament and the older poetics of "The She-Bear". In the right margin, at an unknown time, he has written four lines, of which two are legible: "live in seclusion with purification | the rest of my life". ${ }^{29}$ On another fragment, written around the same time, he exhorts himself once more to:

Follow $\mid$ Bet

Into the colors of her dress

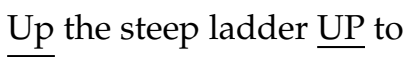

weak

to the face of God

What is needed, he writes, is:

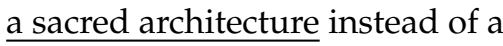

a house

a god instead of a

beloved

marriage a Church

instead of a

Beatrice $^{30}$

His dismissal of Beatrice echoes his denial that he has "any time for any new life", for anything in any way resembling Dante's incipit vita nova. It is not "a | Beatrice" that he needs, but, in his words, "a Church" and sacred architecture. Olson may have despaired of ever representing Betty Kaiser in his poetry as an archetype, on the grounds that an archetypal personification could only be a Beatrice, a spiritual guide or muse on the model of Dante's original. Not only was his grief too sharply felt to be assuaged by devices of personification, but he also, for all of his writing life, rejected the very premise of transcendence, championing the secular, the immanent, and the worldly. What, then, could he possibly have in mind by "Church"? Into what kind of "seclusion" does he plan on retreating?

\section{The Conventual}

In The Law of Civilization and Decay, Brooks Adams traces the rise of our modern "economic age" by means of an unusual barometer, that of "colour", and the supposed decline of its vividness in late medieval art. No "colour ever equalled the windows of Saint Denis and Chartres" he argues, for their makers ably used "marvellous combinations of colour" to evoke corresponding shades of feeling. But, the "mediaeval burgher", being realistic and calculating, wanted something else from art: "representation of the world he saw around him. Hence came perspective" and, eventually, "the final degradation of colour, which sank into a lost art" (Adams 1943, p. 346). Adams dilates on this lost art in a paragraph Olson marked in his copy of The Law of Civilization and Decay and cited in its entirety in a notational composition of 1965, "The Vinland Map Review":

29 Cf. the notebook entry quoted by Clark, written around June of 1969: "Frightful loneliness yet some increase of purification" (Clark 1991, p. 345).

30 Unsorted manuscripts and fragments (1965-1966), box 93, folder 171, CORC. 
When the imagination glowed with all the passion of religious enthusiasm, the monks who built the abbeys of Cluny and Saint Denis took no thought of money, for it regarded them not. Sheltered by their convents, their livelihood was assured, their bread and robe were safe; they pandered to no market, for they cared for no patron. Their art was not a chattel to be bought, but an inspired language in which they communed with God. (Adams 1943, p. 347; Olson 1997, p. 328)

In September, Olson left Buffalo for good, returning to Gloucester. This return is represented in "Maximus of Gloucester" as a farewell to the world and a taking of holy orders. Olson identifies with the monks of Adams' panegyric. He, too, in the person of his heroized self-projection, Maximus, has "sacrificed everything" in the name of "complete | concentration", and this winnowing-out of distraction is part of the conventual regime. Concentration, heightened attentiveness, and sheltered life, lived behind the high walls of a convent, naturally go together:

concentration. (The con-

ventual.) "robe and bread"

not to have to worry about

either (Olson 1983, p. 473)

On the page immediately after "The Acts of Youth", in the blank space under "The Mermaid's Song", Olson has written two lines: "Command Control, so that each day \& night | is solely another one, no matter what". He then adds:

monasticism. Chastity. Contemplation

of God-simply to keep a hold to

What is going on, to take it to

expression [John's rhyme's solely

the formula all great art's made of

Pain. And suffering (woman's

love-not man's, which is "half"

Pity, and love (?

Olson felt an affinity with the monks described by Adams, on grounds that he too had given himself wholly to an art of making color, only by means of his "written word". The unfolding of the peacock's tail is supposed to mean both healing and also reconciliation, a oneness with all the colors of the psyche. It is from the blackness of unrelieved melancholy that the student of alchemy distills the iridescent colors of a multiplied responsiveness to affect. If melancholy and depression involve emotional numbness, recovery could mean a restoration to feeling. In what appears to be a slightly fainter grade of pencil, branching off under the words "pity and love", we find the following:

Friday,

October 9th

Nineteen

Sixty-

Four Follow Bet

Into

The colors of her dress

and up the weak ladder

to the

Face of God 
Olson has transposed the exact same words onto a typescript, only shifting the date into the bottom right corner ("Annex II: Rejected Poems", Butterick 1983, p. 8; Olson 2000a, p. 199). The image of the "ladder" was central to the monastic ideal, and he had encountered at least one comparison of a mythical rainbow bridge, "the color of all colors", to Jacob's ladder, scriptural source of this image (Olson 1983, p. 339; Fowler 1950, p. 241). In his deathbed notes, Olson refers to what he calls "'weak' affective poetry" (Olson 1975c, p. 75), calling to mind "the weak ladder", and he was also in the habit of calling both John Wieners and Ed Sanders "poets of 'affect'" (Olson 2010, p. 229). Wieners was, as Andrea Brady sagely remarks, "a fundamentally personal poet, revealing in verse the most intimate, tender, or appalling preoccupations of his inmost heart" (Brady 2007). Could Olson, then, in the seclusion of his redoubt in Gloucester, have looked to Wieners for an example of how to represent "affect" in writing? What did he mean by the word, "affect"?

There is, at the front of his large sketchbook, a short "Notice", announcing that Ace of Pentacles, a book of "incomparable beautiful poems", now "exists" in the world:

It is a book of poems beyond belief, except by

the greatest $[\ldots]$ and even they, because the

subjects and the means Mr. Wieners uses are

theirs, have suddenly a light and voice thrown

on theirs, from a man just now possibly 30 years old. ${ }^{31}$

Wieners, rather than disclosing a new path for him to follow, had to have recalled Olson to himself, and to "the subjects and the means" of his own poetry. The plea for "strength" enunciated in "The Acts of Youth" would, in October of 1964, have echoed his own thoughts:

Pain and suffering. Give me the strength

to bear it, to enter those places where the

great animals are caged. And we can live

at peace by their side. A bride to the burden

$$
\text { ! }
$$

that no god imposes but knows we have the means

to sustain its force unto the end of our days.

For that it is what we are made for; for that

we are created. Until the dark hours are done.

And we arise again in the dawn.

Infinite particles of the divine sun, now

worshipped in the pitches of the night.

Underneath that last line, Olson has written:

wow,

Exactly

God

31 This "Notice" was probably destined for his contact at the Boston Globe, book reviewer Herbert A. Kenny. Elsewhere in the same notebook we find what looks like a draft of a letter to him: "My dear Herb I hope you will allow me the 'space'. At least the 'Notice' is an honourable news-letter means, and the two selections will give you, too, my 'reason' Yours, Charles". I have found no indication of what "selections" he may have had in mind. 
On the previous page, he aligns the wish to "eat the lotus in peace" with the desire, not to lose oneself in forgetfulness, but to "contemplate God". Olson goes on to say that "Contemplation | of God" is undertaken "simply to keep a hold to | What is going on"- to pay attention to what is transient and moving, "going on" and not at rest. The "God" he has in mind is not, then, exempt from temporality, but manifest in the temporal world. This reflects what he had learned from Whitehead, obviously, but also his own persistent idealization of an attentiveness so focused that nothing escapes its notice-an attention span able to "keep a hold to" what, like Proteus, would defy its grasp and slip by unnoticed. Distractedness involves the misuse of time, and this is precisely what monastic life is supposed to minimize or eliminate. Monasticism means an unfaltering attentiveness to the hours of the day and night, their specific ordinances and offices. Olson, under "The Mermaid's Song", seems to remonstrate with himself to take better care of his time, to exert enough "Control" (self-control?) to make sure "each day \& night is solely lanother one". But, is he simply advising himself, here, to take one day at a time, to manage the grieving process by sticking to small steps?

Olson, assuming he looked up the word "colour" in his oft-used Encyclopaedia Britannica, would have learned of its lexical basis in "Lat. color, connected with celare, to hide, the root meaning, therefore, being that of a covering" (11th ed., s.v. "Colour"). His next move would have been to consult the entry

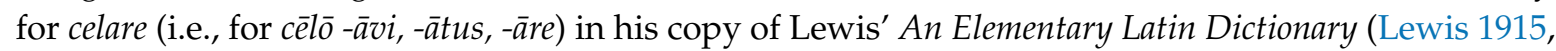
p. 119). The word means "To conceal, hide, cover, keep secret", and shares the root "2 CAL-, SCAL-", which generally signifies "cover, hide" in many formations besides "cēlō, color"—-cf. Germ. hehlen, hüllen, Höhle; Engl. Hull, hell, hole, hall" (Lewis 1915, pp. 119, 938). The intersection of color and cover, of the "colors of her dress" and the condition of being "covered", may have led him to the poem he called "Bet 2":

Her skin

covered me, let light into me, held

my nature, kept me

for myself, and I wasn't sorry

to be closer. In the horrors and transparent

policy,

of the present... ${ }^{32}$

This typescript was made on the same night as the others, Friday, "October 9th, | 1964", but the poem is not to be found written inside of Ace of Pentacles. He has, however, on the very back page, written a column of writing that begins this way:

Stay close

to her, at no matter what cost.

She is-she was, she does cover

your soul ...

This suggests what it might mean to go into "the colors of her dress" - to keep close to her memory, not "sorry | to be closer" to it than to those "other outside things" he passively gestures at in "'Additions' March 1968-2" (Olson 1983, p. 585). The directive above, to do whatever it takes to "Stay close | to her", might also help illuminate what "the close" meant to him as both a topos and a discipline (Olson 2010, p. 145). His isolation in Gloucester after Betty Kaiser died suggests to his biographer, Tom Clark, a compensatory marriage to his vocation, to "poetry, now to be Olson's final, enduring close companion" (p. 315). It is not that, from then on, he was twice as industrious, but that the very quality of the attention he paid to his writing changed. The quarrel over the biographical facts of Olson's life is also an argument about the nature of this change and the best way of defining or delimiting it. One of Clark's most memorable formulations is the second sentence of this passage:

32 See Byrd 1980, p. 188; Olson 2000a, pp. 199-200; compare Olson 1987, p. 614. 
"Follow Bet", he'd urged himself in one fragment written after the calamity of his wife's death, "into the colors of her dress/and up the weak ladder/to the Face of God". The image of approach to godhead in his writings now metamorphosed from an ascent to an inward spiral, a furling of being into the sunlike vortex of the soul. (p. 327)

This bodes ill, Clark warns us, for the making of Olson's future poetry, his dive "inward" being an omen of bad things to come. The hoped-for illumination, that of the soul's center, the fabled "helio inside" (as he had called it, at Beloit College), does not break over the last of The Maximus Poems, which, Clark argues, fall apart in fragments, both figuratively and literally, buried under the layered referentiality of extraneous sources, too many to name, and also written in bits and pieces, committed to the most ephemeral and frail of surfaces, guaranteeing that volume three was to be an editorial nightmare.

\section{Kingston}

The word Kingston, dictated to Olson in a dream, resurfaces in the pages of his oversized sketchbook. All alone on one of the large white sheets he has written "Kingston |-Kingston" and, on another, "Kingson | Kingston". It is as though, exasperated by its inscrutability, he had no choice but to take this word apart letter by letter. Witness what happens in the typescript we have seen already:

A Maximus:

$$
\text { Kingson, Kings- }
$$

ton

King(s)son Kings-

(s)ton

\section{Wednesday October 24th 1964}

A "hero", he had written in August, "has to be the king's Son". ${ }^{33}$ This is in an autobiographical statement he had sent to Donald Allen:

The old man has to die, you have to succeed, and not that one, here, of success: it has to be rule. You are omnipotent. Thus you do be what you were which you were born for. The illusion of yourself as such, is the third of the three crowns. (Olson 1967, pp. 326-27)

Who, then, is the "king's Son"? He and Wieners were, he once announced, bearers of the same Irish-Catholic religious conscience: "Despite the name Olson, I come also of the Church and blood" (Olson 2010, p. 225). Around 1963, he began, in Clark's words, "quoting the Lord's Prayer as a sort of esoteric mystic mantra" (p. 319). In the upper left margin of the poem on p. 33 of Ace of Pentacles (Figure 6), "My Mother", Olson has written his own free variation of the Lord's Prayer:

33 A major portion of Part III, Chapter 4, of Psychology and Alchemy is given over to the lugubrious psychospiritual allegory of "The King and the King's Son". See pp. 313-31. Butterick dates the note to August 12, 1964 (Butterick 1978, p. 5). 


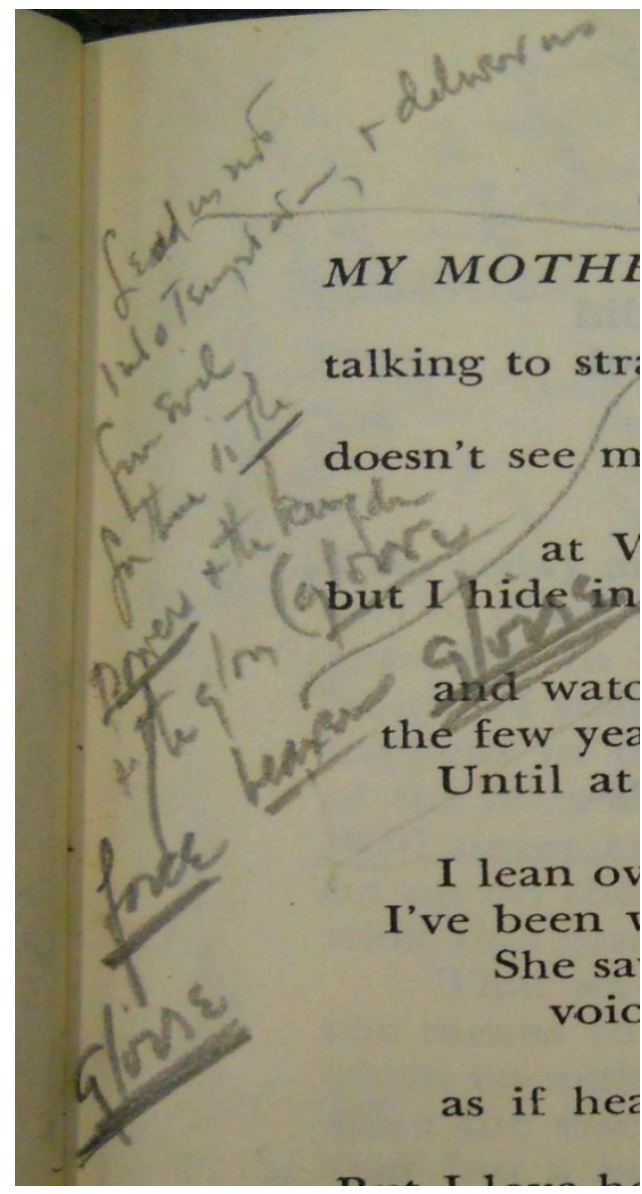

Figure 6. Page 33 of "Manuscript. Written on 'Ace of Pentacles' by John Wieners", box 24, folder 1147, CORC.

Lead us not

into temptation, \& deliver us

from evil

for thine is the

Power \& the kingdom

\&|the glory (gloire)

Force heaven gloire

gloire

A gloss of what he is doing can perhaps be found in a letter to Harry Martin, a Gloucester painter, sent in January of 1965. The letter resumes an earlier conversation in which, evidently, there was resistance on Martin's side to hearing anything of interest in the words of the Lord's Prayer. Olson answers that:

I came myself to believe in the (so-called) Lord's Prayer-and my own experience also argues that His Kingdom, and Power, and Glory-just those abstract (or, as you feel them rhetorical) phrases equally can be attested as party—as the figure one's own father to Father: one's own realm or place, "power"-in the sense actually of a route for our own personal forces. (Olson 2000b, p. 319) 
The words "power" and "force" come back again; when he tells Martin to heed the efficacy of "one's own realm or place", we cannot but think back to "the secret place" of which Wieners had written in Ace of Pentacles. Could the "place", then, where we are sure to "go to in time" and where pain abates for good, be the numinous topos of which his dream had spoken, Kingston? A few days after he set Ace of Pentacles aside, Olson wrote another Lord's Prayer, this time with the talismanic word at its very center:

Kingston

the smell of her

Heaven Our Father who Art in Kingston

Hallowed be Thy Name Thy Kingston come

on Earth as it does in Heaven by the Power

and Glory the Glory that in addition to the Kingdom

Your Name \& Power \& Place Are ${ }^{34}$

In the bottom right corner is a conjectural date: "Tues? Wed? | Oct 13th?" The unverified dateline might imply that this poem was not so important to Olson (or, simply that he did not know what the date was). But, the intentions behind its composition are very hard even to guess at. Could this be part of a major turning-point in his authorship, representing his recognition of a saving religious "power"? Or does the sequence that runs from "Kingston" to the figure of the "king's Son" to the promise of a "Kingdom" dry up in a dead end, a bemused experiment with words? Was the Lord's Prayer, in some way, as important to Olson as the satanic motto was to Melville?

I have compared the threatening "dead leaves" he beheld at Woodlawn Cemetery to the indeterminacy of the markings in Melville's Shakespeare set. Olson's discovery, genuinely ground-breaking, had to have seemed, sometimes, strangely ambivalent to him-both promising, and also concealing, enormous depths of meaning. Anyone who reads his own annotations in Ace of Pentacles might have a similar sense of chasing elusive intimations of a larger picture that never fully comes into view. Adjacent materials help establish that Olson found consolation in Ace of Pentacles, and that Wieners was a consoler to him. But my analysis covers a bare fraction of the annotations, which implicate other horizons of reference beyond those examined so far. Loose ends abound in many places. It is, perhaps, possible to interpret his marked-up copy of Ace of Pentacles the same way he did the satanic baptismal formula at the back of the volume of Shakespeare. We, or some imaginary heir to Olson's poetics, could, perhaps, try to read his elegiac sequence of poems to Betty Kaiser as the basis of an as-yet unwritten version of The Maximus Poems, volume three-another possible book that we ourselves will have to reconstitute, somehow, on his behalf, and that only our own time, with its specific determinations, could disclose to us. The sum of the marginalia would then represent curtailments of something yet to emerge from its condition of abatement, incompleteness, and abbreviation. Maud suggests that "Olson's last five years in Gloucester were a step forward into some new thing that we haven't got the means to portray. Yet." (Maud 2009, p. 39). In the meantime, then, the more immediate task may simply be that of learning to read already available versions of volume three in light of the manuscript wilderness all around them.

Funding: This research was supported by a Rose and Sigmund Strochlitz Travel Grant, awarded to the author by the Thomas J. Dodd Research Center at the University of Connecticut Library.

Acknowledgments: Works by Charles Olson published during his lifetime are held in copyright by the Estate of Charles Olson; previously unpublished works are copyright of University of Connecticut. Used with Permission. All quotations from John Wieners reproduced by kind permission of Raymond Foye, for the Estate of John Wieners. Valuable comments on a draft of this essay were provided by Elizabeth Edwards. Ron Huebert advised on an

34 "Annex II: Rejected Poems", Butterick 1983, p. 9. Note how the sound contour of lines one and two, "Kingston | the smell of her" is very close to that of a line in "Maximus of Gloucester", "Half Moon beach ('the arms of her')" (Olson 1983, p. 473). 
important query. I am grateful to Simon Kow for his feedback on another draft. Any errors or misjudgments in this essay are, of course, entirely my own. After presenting a paper on Olson's Melville scholarship in October of 2010 I was informed by Justin Katko that there was a "poem" on the front flyleaf of his copy of Ace of Pentacles and asked what I would make of his writing it there (in fact there are dates and notes on the front flyleaf, as we have seen; but on the torn-off inside front cover there is a composition that could be called a poem). This essay is in part a belated response, after almost a decade, to this question of Katko's, for which I want to thank him. Melissa Watterworth Batt, Archivist for Literary Collections and Rare Books at the Thomas J. Dodd Research Center, was indefatigably helpful when I was there. I am grateful to Patricia Chalmers, assistant librarian at the University of King's College, for her help with out-of-the-way materials.

Conflicts of Interest: The author declares no conflict of interest.

\section{References}

Adams, Brooks. 1943. The Law of Civilization and Decay. New York: A.A. Knopf.

Bernstein, Michael André. 1980. The Tale of the Tribe: Ezra Pound and the Modern Verse Epic. Princeton: Princeton University Press.

Bernstein, Charles. 2001. Undone Business. In Content's Dream: Essays, 1975-1984. Evanston: Northwestern University Press.

Boer, Charles. 1975. Charles Olson in Connecticut. Chicago: Swallow Press.

Brady, Andrea. 2007. The Other Poet: John Wieners, Frank O'Hara, Charles Olson. Jacket 32. Available online: jacketmagazine.com/32/brady-wieners.shtml (accessed on 12 November 2018).

Butterick, George F. 1978. A Guide to the Maximus Poems of Charles Olson. Berkeley: University of California Press. Butterick, George F. 1981. Modern Literary Manuscripts and Archives: A Field Report. Credences: A Journal of Twentieth Century Poetry and Poetics 1: 81-104.

Butterick, George F. 1983. Editing the Maximus Poems. Storrs: The University of Connecticut Library.

Byrd, Don. 1976. For Complete Concentration. Credences 3: 101-14.

Byrd, Don. 1980. Charles Olson's Maximus. Urbana: University of Illinois Press.

Byrd, Don. 2013. The Making of the Archive. Open Letter 15: 84-110.

Charters, Ann, and Charles Olson. 2015. Evidence of What Is Said: The Correspondence between Ann Charters and Charles Olson on History and Herman Melville, with an Introductory Essay and Photographs of Olson in Gloucester by Ann Charters. Portland: Tavern Books.

Clark, Tom. 1991. Charles Olson: The Allegory of a Poet's Life. New York: W.W. Norton \& Company.

Clarke, John. 2016. "The 28 Phases of Charles Olson" and "The Archeology of Morning: Causal and Applied-" (1965). Paideuma 43: 51-138.

Clarke, John. 2019. John Clarke to Tom Clark-Correspondence 1985-1986, with an Introduction by Michael Bohn. Dispatches from the Poetry Wars. Available online: dispatchespoetrywars.com/documents/john-clarke-to-tomclark-correspondence-1985-1986-with-an-introduction-by-michael-boughn/ (accessed on 7 May 2019).

Corbett, William. 1998. Letter from William Corbett. Minutes of the Charles Olson Society 26: 10-14.

Damon, Maria. 2014. John Wieners in the Matrix of Massachusetts Institutions: A Psychopoeticgeography. Journal of Beat Studies 3: 69-92.

Dewhurst, Robert Stuart. 2014. Ungrateful City: The Collected Poems of John Wieners. Ph.D. dissertation, The University at Buffalo, State University of New York, Buffalo, NY, USA.

DuPlessis, Rachel Blau. 2012. Sex/Gender Contradictions in Olson and Boldereff. In Purple Passages: Pound, Eliot, Zukofsky, Olson, Creeley, and the Ends of Patriarchal Poetry. Iowa City: University of Iowa Press.

Eliade, Mircea. 1960. Myths, Dreams and Mysteries: The Encounter Between Contemporary Faiths and Archaic Realities. Translated by Mairet Philip. New York: Harper.

Eshleman, Clayton. 2004. Notes on Charles Olson and the Archaic. Minutes of the Charles Olson Society 52. Available online: charlesolson.org/Files/EshlemanNotes.htm (accessed on 10 March 2017).

Fowler, Murray. 1950. Old Norse Religion. In Ancient Religions. Edited by Vergilius Ferm. New York: Philosophical Library, pp. 237-50.

Fredman, Stephen. 2013. The Contemporaries: A Reading of Olson's “The Lordly and Isolate Satyrs”. Open Letter 15: 25-39.

Friedlander, Benjamin. 2007. Preface: Charles Olson Now. In Olson's Prose. Edited by Gary Grieve-Carlson. Newcastle: Cambridge Scholars Publishing, pp. vii-ix. 
Harrison, Jane. 1890. The Mythology of Athenian Local Cults. In Mythology \& Monuments of Ancient Athens: Being a Translation of a Portion of the "Attica" of Pausanias by Margaret de G. Verrall, with Introductory Essay and Archaeological Commentary by Jane. E. Harrison. London: Macmillan, pp. xxi-clvi.

Harrison, Jane. 1913. Ancient Art and Ritual. New York: Henry Holt Home Library of Modern Knowledge.

Jung, C. G. 1953. Psychology and Alchemy. New York: Pantheon.

King, Martha. 2010. Three Months in 1955: A Memoir of Black Mountain College. Jacket 40. Available online: jacketmagaze.com/40/king-martha-black-mountain.shtml (accessed on 14 September 2018).

Lewis, Charlton T. 1915. An Elementary Latin Dictionary. New York: American Book Company.

Maud, Ralph. 1976. Review of The Maximus Poems Volume Three, by Charles Olson, ed. by Charles Boer and George Butterick, and The Collected Books of Jack Spicer, ed. by Robin Blaser. West Coast Review 10: 32-34.

Maud, Ralph. 1980. Charles Olson: Posthumous Editions and Studies. West Coast Review 14: 27-33.

Maud, Ralph. 1981. Charles Olson: Posthumous Editions and Studies (Part 2). West Coast Review 15: 37-42.

Maud, Ralph. 1996. Charles Olson's Reading: A Biography. Carbondale: Southern Illinois University Press.

Maud, Ralph. 2008. Charles Olson at the Harbor. Vancouver: Talonbooks.

Maud, Ralph. 2009. An Interview with Ralph Maud By Stephen Collis, Tony Power and Jason Starnes. The Capilano Review 3: 25-42.

Melville, Herman. 1988. Moby-Dick, or, The Whale. Evanston: Northwestern University Press; Chicago: The Newberry Library.

Melville, Herman. 1993. Correspondence. Evanston: Northwestern University Press; Chicago: The Newberry Library.

Melville, Herman. 2009. Published Poems: Battle-Pieces, John Marr, Timoleon. Evanston: Northwestern University Press; Chicago: The Newberry Library.

Melville, Herman. 2018. Moby-Dick, ou le Cachalot. Édition établie et présentée par Philippe Jaworski. Paris: Gallimard.

Miles, Barry. 1997. CHARLES OLSON Reads from MAXIMUS Poems IV, V, VI. Minutes of the Charles Olson Society 21: $2-3$.

Olson, Charles. 1933. The Growth of Herman Melville, Prose Writer and Poetic Thinker. Master's dissertation, Wesleyan University, Middletown, CT, USA.

Olson, Charles. 1967. Biographical Note. In The New Writing in the USA. Edited by Donald Allen and Robert Creeley. Harmondsworth: Penguin, pp. 326-27.

Olson, Charles. 1975a. The Maximus Poems Volume Three. Edited by Charles Boer and George F. Butterick. New York: Grossman.

Olson, Charles. 1975b. His house/in the branches. OLSON: The Journal of the Charles Olson Archives 4: 30.

Olson, Charles. 1975c. Charles Olson, the Secret of the Black Chrysanthemum. OLSON: The Journal of the Charles Olson Archives 3: 65-81.

Olson, Charles. 1983. The Maximus Poems. Edited by George F. Butterick. Berkeley, Los Angeles, and London: University of California Press.

Olson, Chares. 1987. The Collected Poems of Charles Olson: Excluding the Maximus Poems. Edited by George F. Butterick. Berkeley, Los Angeles, and London: University of California Press.

Olson, Charles. 1992. Lear and Moby-Dick. In Critical Essays on Herman Melville's Moby-Dick. Edited by Brian Higgins and Herschel Parker. New York: G.K. Hall \& Co., pp. 265-84.

Olson, Charles. 1997. Collected Prose. Edited by Donald Allen and Benjamin Friedlander. Berkeley, Los Angeles, and London: University of California Press.

Olson, Charles. 1999. Olson on Chase. Minutes of the Charles Olson Society 28: 14-17.

Olson, Charles. 2000a. Poems for Bet. Edited by Ralph Maud. Sulfur: A Literary Bi-Annual of the Whole Art 45/46: 195-200.

Olson, Charles. 2000b. Selected Letters. Edited by Ralph Maud. Berkeley: University of California Press.

Olson, Charles. 2004. Charles Olson's Melville Project. Available online: lib.uconn.edu/location/asc/collections/ the-charles-olson-research-collection/charles-olsons-melville-project/ (accessed on 26 April 2019).

Olson, Charles. 2010. Muthologos: Lectures and Interviews: Revised Second Edition. Edited by Ralph Maud. Vancouver: Talonbooks.

Olson, Charles, and Jeremy Prynne. 2017. The Collected Letters of Charles Olson and J. H. Prynne. Edited by Ryan Dobran. Albuquerque: University of New Mexico Press. 
Olson, Charles, and John Wieners. 2012. "the sea under the house": The Selected Letters of John Wieners and Charles Olson. Edited by Michael Seth Stewart. New York: Lost and Found, CUNY Poetics Document Initiative, vol. 2.

Rumaker, Michael. 2012. Black Mountain Days. New York: Spuyten Duyvil.

Sanborn, Geoffrey. 1992. The Name of the Devil: Melville's Other "Extracts" for Moby-Dick. Nineteenth-Century Literature 47: 212-35. [CrossRef]

Sealts, Merton. 1982. Pursuing Melville, 1940-1980. Madison: The University of Wisconsin Press.

Stewart, Michael Seth. 2014. "For the Voices": The Letters of John Wieners. Ph.D. dissertation, The City University of New York, New York, NY, USA.

Sutherland, Keston. 2012. The World and John Wieners. World Picture 7. Available online: worldpicturejournal.com (accessed on 1 November 2018).

Wieners, John. 1964. Ace of Pentacles. New York: James F. Carr \& Robert A. Wilson.

Witthus, Rutherford W. 1998. News from Storrs. Minutes of the Charles Olson Society 23/24: 8-12.

(C) 2019 by the author. Licensee MDPI, Basel, Switzerland. This article is an open access article distributed under the terms and conditions of the Creative Commons Attribution (CC BY) license (http://creativecommons.org/licenses/by/4.0/). 